\title{
Fotografia e memória de gestos cênicos. Estudo sobre velhice e linguagem teatral
}

\section{Photography and memory scenic gestures. Study of old age and theatrical language}

Beatriz Pinto Venancio ${ }^{1}$ 


\section{Resumo}

O artigo é resultado de pesquisa com teatro, memória e fotografia junto a velhos sujeitos participantes de uma oficina criada em 1999 e é parte de um Programa de Extensão da Universidade Federal Fluminense, voltado para a população idosa. Os fragmentos de memória, material bruto para exercícios de escrita dramatúrgica, despertaram interesse em conhecer mais as vidas destes velhos sujeitos. Por esta razão, iniciamos a criação de um arquivo de histórias de vida. Outro arquivo foi se construindo com fotografias dos espetáculos teatrais. $\mathrm{O}$ objetivo aqui é mostrar o uso da fotografia da cena como provocadora de memórias. Quatro mulheres foram escolhidas e solicitado que selecionassem fotos de cenas em que estavam presentes. A sequencia de fotos tornou-se um roteiro imagético para contar a própria vida. A análise permitiu perceber o modo como cada uma justificou suas escolhas e enquadrou a memória de uma maneira singular.

Palavras-chave: Memória; envelhecimento; teatro; fotografia

\section{Abstract}

The article analyses the relation among theater, memory and photograph in a workshop dedicated to elderly people, developed at Universidade Federal Fluminense since 1999. Based in memories, the material for dramaturgical writing exercises aroused interest of those lives. For this reason, we have organized a life history and a photograph of theatrical performances archives. The research analyses how the photos of performances trigger memories. Therefore four women chose some of their photos in performances. The chosen photos would be a script to tell their lifes. The analysis allowed understanding how each one justified their choices and framed the memory in a unique way.

Keywords: Memory; aging; theater; photography
ISSN: 1414.5731

E-ISSN: 2358.6958

${ }^{1}$ Profa. Dra. Universidade Federal Fluminense (UFF), Rio de Janeiro (RJ). beavenancio@uol.com.br 
Na hora combinada, Eunice compareceu ao encontro marcado. Era o início de mais uma gravação de história de vida para o arquivo que venho criando há alguns anos, um minúsculo "guarda-memória"2. Ela, naquele momento com oitenta e três anos, chegou com uma sacola pesada. Tirou dali dois grandes álbuns de fotografia e me disse "você quer saber a minha vida, então eu trouxe isto aqui para mostrar". Foi pelas fotos que me contou a sua história, que ia e voltava de acordo com os registros ali contidos. Poderia ter trazido cartas, diários, algum objeto. Mas trouxe fotografias para construir a sua versão sobre os acontecimentos vivenciados e assumir o comando de sua narrativa. O seu relato era entrecortado por comentários técnicos sobre as imagens, como foco e luz. A escolha do suporte imagético para contar a sua vida se revelava, neste e em outros detalhes, como um interesse forte e antigo pela fotografia e o desejo de uma "máquina fotográfica das boas", comprada com economias em um dezembro qualquer.

As fotos forneciam um roteiro para a sua história, no entanto, a cronologia não se estabelecia, pois minhas perguntas, como provocação de memórias, levavam a "saídas de todos os lados" (Samain, 2003, p.64), explorando e cruzando lembranças.

Sete anos depois, ao me debruçar sobre o material da pesquisa ${ }^{3}$ percebi o potencial das fotografias em narrativas de memória. Afinal, desde os anos 1930 e 1940, com máquinas fotográficas baratas e de fácil manuseio, a vida de indivíduos e grupos "passou a ser registrada muito mais pela imagem do que pelos livros de memórias, cartas ou diários" (Von Simon, 2005, p.20)4. Este material a ser analisado contemplava as fotografias das apresentações teatrais de um grupo de teatro de idosos não-atores que coordeno, ${ }^{5}$ os doze exercícios de escrita dramatúrgica produzidos com fragmentos de memórias dos participantes do grupo e o conjunto de histórias de vida de alguns deles, coletadas em minuciosas entrevistas realizadas por mim.

Pensar sobre um trabalho em que o envolvimento é grande, seja pela peculiaridade da experiência com a linguagem teatral, seja pelos inúmeros anos de convivência, não é tarefa simples. Como criar um distanciamento mínimo e necessário? A escolha da metodologia foi fundamental para levar a proposta a termo. Poderia dizer que Eunice e suas "imagens-relicário" (Kossoy, 2005, p.42) me apontaram o caminho. Ao ouvir suas entrevistas, fui desenhando um percurso metodológico e descobrindo a força do conjunto de fotografias que ela acessava para "descongelar" o seu passado. Sua história, ela contava percorrendo as fotos de família, ou com amigos e vizinhos. As fotos apresentadas por ela, revelavam sua maneira de pensar a vida e o mundo. Surgiu, então, a questão norteadora deste artigo: o que contaria, ou melhor,

\footnotetext{
2 No artigo 0 guarda-memória, Philippe Lejeune comenta sobre a bonita expressão utilizada pela Association pour l'autobiographie em Ambérieu-en-Bugey (Ain, France), para nomear o catálogo do acervo de textos autobiográficos, comparando-a com o guarda comida e o lembrete. Não esquecer e "[...] conservar a vida em local fresco" (LejeunE, 1997). Foi neste sentido que utilizo aqui.

3 Esta pesquisa é parte de Pós-doutorado em antropologia visual, realizado no PPCIS/UERJ, sob orientação de Clarice Ehlers Peixoto, em 2015.

4 Ver também Peixoto, 2013, p.9. In: Copque; Peixoto; Luz, 2013.

5 A Oficina de Teatro e Memória, criada em 1999, é um projeto de extensão da UFF, vinculado ao UFF Espaço Avançado. O grupo, atualmente, conta com cerca de quarenta pessoas idosas. Quase a totalidade teve contato com a linguagem teatral neste projeto. O grupo é aberto, sem processo seletivo. As oficinas contemplam exercícios e jogos para qualificar a atuação no palco e para a construção de textos com as lembranças. Os textos das apresentações são criados coletivamente pelo grupo e levam, em média, seis meses para serem concluidos. Durante estes anos, nos apresentamos nos mais diferentes espaços, como teatros, sindicatos, colégios, praças, auditórios e instituições de longa permanencia para idosos. O que será apresentado aqui não seria possível sem a generosidade destes velhos sujeitos que ofereceram suas histórias e dos estudantes inquietos e curiosos que participaram do projeto ao longo destes anos. Duas parcerias também foram fundamentais, uma antiga com Maria Carmen Vilas-Bôas Hacker Alvarenga, coordenadora do Programa UFF Espaço Avançado, e outra mais recente com Marisa Alvarenga, do grupo As cantadeiras do Tresfolia, que há alguns anos assumiu a direção musical do grupo. A acolhida carinhosa e orientação precisa de Clarice Peixoto, que me recebeu no INARRA, PPCIS/UERJ, para realizar a pesquisa de pós-doutorado, também deve ser registrada.
} 
como contaria sua vida diante do registro fotográfico das apresentações teatrais que participou? $^{6}$

A leitura de vários trabalhos guiaram minhas opções metodológicas ${ }^{7}$ e possibilitaram pensar fotografia ${ }^{8}$ e memória ${ }^{9}$ para construir a análise aqui proposta. $\mathrm{O}$ cotejamento das fotografias das apresentações, dos exercícios de escrita dramatúrgica e as histórias de vida forneceram o primeiro campo para análise. Quatro mulheres ${ }^{10}$ foram escolhidas, entre os quarenta participantes, porque pertencem ao grupo desde o início, participaram de todos as apresentações teatrais e suas histórias de vida constam do nosso acervo.

As vidas narradas destas idosas já carregavam em si o "discurso de um olhar" (Achutti, 2004, p.111) que imprimia movimento ao passado, buscando "ilustrar" o dito com algumas imagens. Se Eunice chegou com as fotos, Rosalina trouxe livro e revista para comprovar as suas conquistas, Conceição se esmerou nos detalhes e Gabriela construiu, com habilidade de contadora, inúmeras imagens de sua vida. Três delas nasceram na década de 1920 e a outra em 1941. Apenas uma não teve relacionamento próximo com a avó, as outras três coabitaram com as avós, recebendo influências e cuidados. ${ }^{11}$ Com infância pobre e histórias de vida distintas, estas mulheres se encontraram na velhice pelo interessem em comum no teatro e pela possibilidade de realizar um desejo que parecia impossível, o de subir ao palco para falar de si e de outros com histórias que se cruzam e abrir o "guarda-memórias"; pintar dores mal curadas com humor; emprestar e tomar emprestado lembranças para imprimir outras alternativas à vida. Porque é deste modo que construímos os textos que são apresentados e compartilhados com o público. É o nosso esforço em formar uma "comunidade de destino" (Bosi, 2003,152).

O que a experiência trouxe para cada uma delas? Quais alterações a sociabilidade neste grupo imprimiu no olhar que elas lançam hoje para o passado a partir das imagens capturadas nas apresentações teatrais? Estas são algumas das questões que nos convidaram a refletir sobre o material aqui apresentado, conjugando memória e imagem.

\section{Fotos de gestos cênicos - provocação da narrativa}

Após a análise do arquivo de fotos, selecionei quinze imagens de cada uma das quatro mulheres, procurando contemplar apresentações de todos os textos dramáticos criados. Além deste critério, as fotografias deveriam revelar um gesto cênico que as provocasse de alguma forma e seriam o "start da lembrança" (Kossoy, 2005, p.43)

\footnotetext{
6 Ver Peixoto (2012) sobre o importante papel da fotografia na reconstituição da trajetória de um sujeito.

7 Bruno, 2003 e 2009; Moraes, 2005; Peixoto, 2000.

8 Kossoy, 2005; Dubois, 1994; Samain, 2003, 2005 e 2006.

9 BOSI, 1994; MuxeL, 2002; Million-Lajoinie, 1999.

10 Rosalina Rodrigues Santiago, Eunice Costa Pinto, Maria Gabriela Calheiros Alvarenga e Maria da Conceição Gomes Vieira permitiram o uso de suas imagens e de seus nomes verdadeiros neste artigo. Assinaram o termo de consentimento livre e esclarecido.

11 Sobre avós e netos, ver Lins de Barros, M. (1987) e Peixoto, C.E. (2007).
} 
para que cada história fosse contada. Incompleta, repleta de hiatos, enfeitada, não importava. De antemão, sabemos que o passado não está lá, fixo, e aquele que conta cria e reinventa a si próprio, na maioria das vezes, sem má-fé alguma, pois a memória sofre flutuações em função do momento. "O que a memória individual grava, recalca, exclui, relembra, é evidentemente o resultado de um verdadeiro trabalho de organização" (Pollak, 1992, p. 204).

As fotografias selecionadas foram apresentadas ${ }^{12}$ às entrevistadas: Rosalina, Eunice, Gabriela e Conceição. Pedi que levassem para casa, examinassem tranquilamente, sem pressa. Junto a esta tarefa, algumas provocações: a que elas remetem? Há relação da interpretação que fazem da foto com o que estava sendo representado cenicamente no momento em que a foto foi feita? Com este convite elas teriam interferência ativa na pesquisa, tornando-se parceiras do que será exposto a seguir.

Algumas semanas depois, foi marcada uma entrevista individual com cada uma. Pedi que falassem um pouco sobre todas as fotos, escolhessem apenas cinco, ordenassem e contassem a sua vida a partir delas. Haveria relação das escolhas das cinco fotos com o momento em que estavam vivendo agora, ou de momentos do passado? Para pensar esta questão e situar estas mulheres, acessei também as falas presentes nas histórias de vida.

\section{A linha do tempo de Rosalina}

Rosalina, filha de mãe solteira há setenta e quatro anos atrás, veio ao mundo para resistir e foi esta noção de resistência que marcou o seu discurso. Seu nascimento foi escondido da família e ela deixada na rua; quando encontrada por transeuntes foi levada à delegacia local. Como sua avó era a parteira da região e havia tido um filho recente, os guardas resolveram levar a criança até lá para ser amamentada. No momento do banho, um parente identificou um sinal no corpinho do bebê, uma amora negra, que era comum na família. A avó, então, começou a desconfiar da mudança da filha para a casa de uma amiga. Foi até lá e descobriu o ocorrido. Assim ela começou a nossa entrevista para o arquivo de histórias de vida, em setembro de 2006.

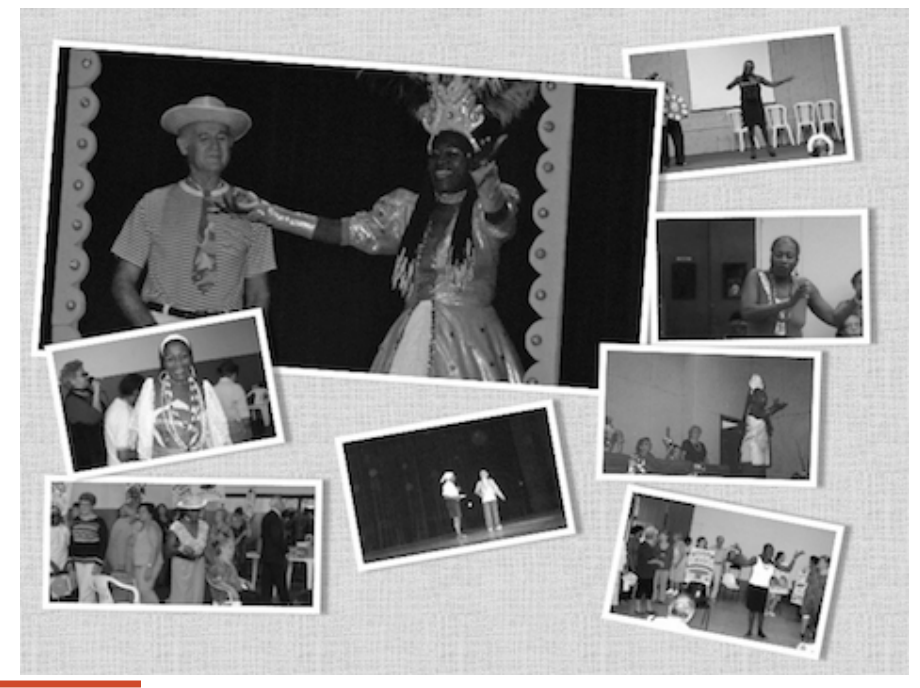

12 Clarice Peixoto trata do procedimento do feed-back. "A memória em imagens tem sido muito explorada pela antropologia, particularmente pela antropologia visual através do procedimento de feed-back [...] Um instrumento que incita as pessoas filmadas [e fotografadas] a discorrerem sobre as imagens projetadas: imagens do outro, imagem de si” (2001, p.174). 


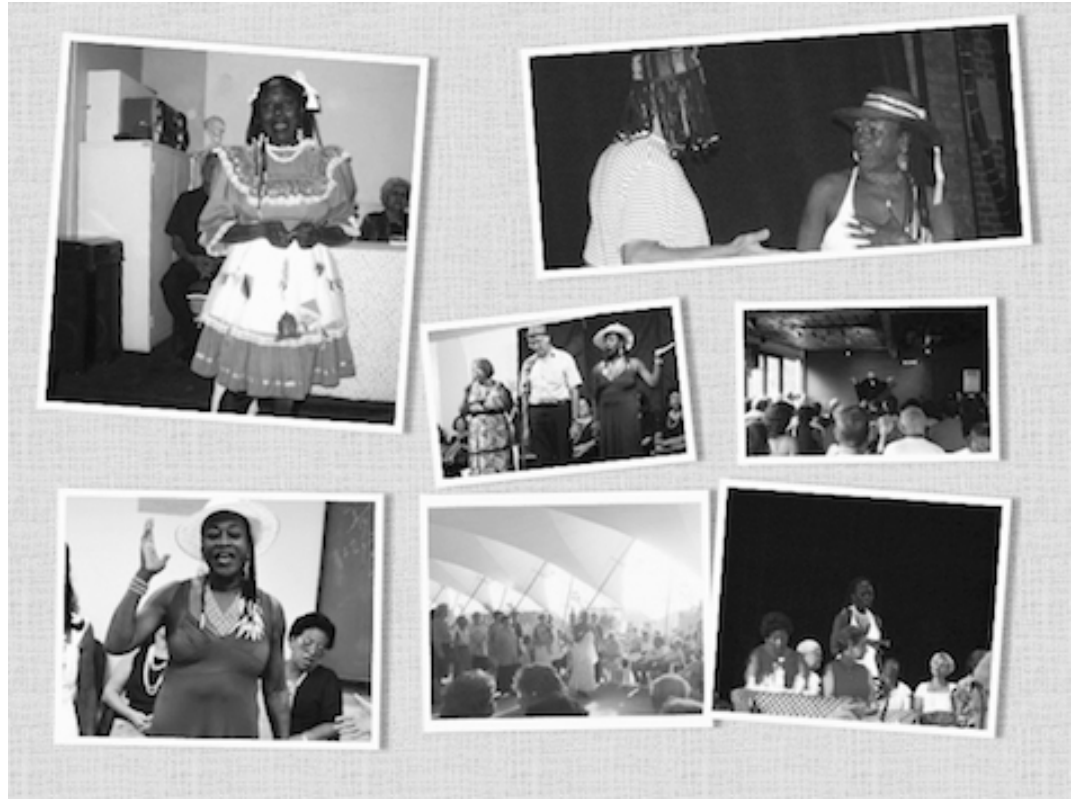

Imagem 2 - Composição Rosalina

$\mathrm{Na}$ entrevista, em maio de 2015, ela mesma espalhou as quinze fotos sobre a mesa, falou longamente sobre o conjunto, relacionando cada uma delas com momentos de sua vida. Sem dificuldade para escolher as cinco fotos e as ordenar, não seguiu uma ordem cronológica das apresentações, mas construiu a sua sequência com fases da vida, da infância até os dias de hoje.

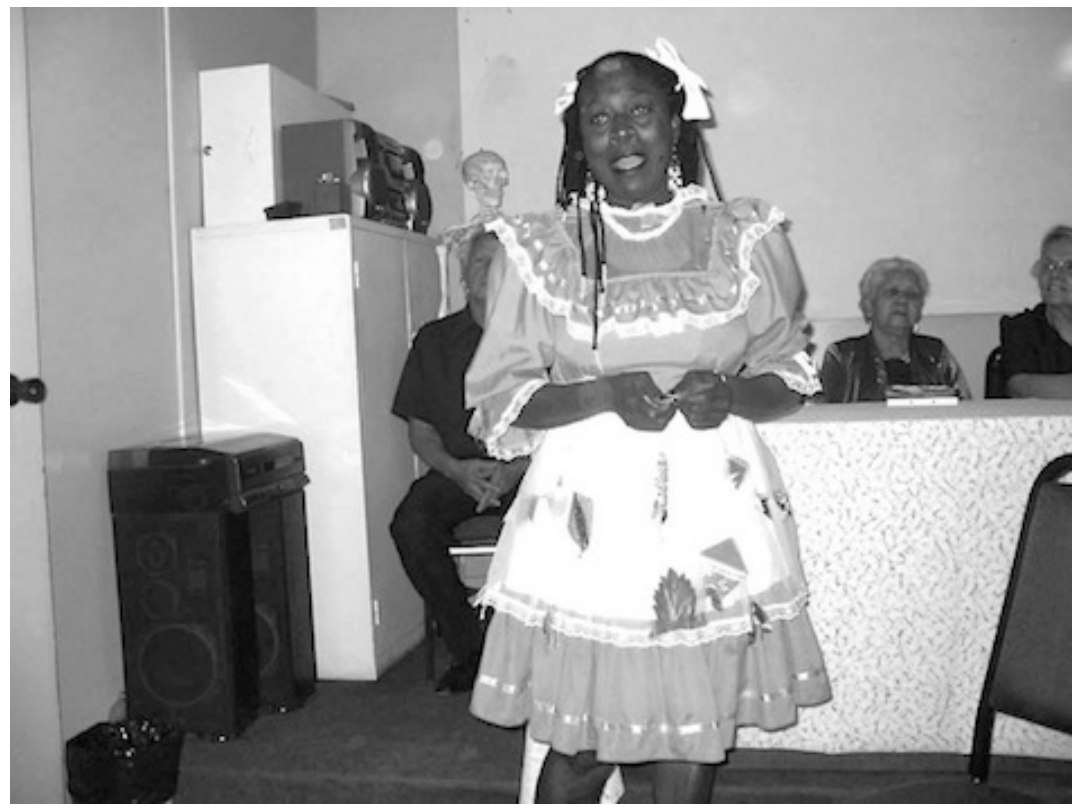

Imagem 3 - Boneca

Sobre a primeira foto, ela se reportou à infância, trazendo para a narrativa um cenário que ficou para trás.

13 Todas as imagens utilizadas neste artigo são de autoria de Beatriz Pinto Venancio e constituem o acervo do projeto Oficina de Teatro e Memória. 
Tem foto ali que me dá uma tristeza da época em que peça em si foi feita, que foi a época de sofrimento. [...] Mas tem outras que me dão muito alegria, a boneca, ${ }^{14}$ por exemplo. Aqui eu me sinto realmente criança, de coração aberto para fazer esta boneca. Às vezes, a gente queria uma bala e não tinha. Eu nunca tive uma boneca quando era criança.

Lembrou da infância "difícil e muito triste". Quando seus pais se casaram, ela tinha sete anos. Teve outros irmãos, mas nunca se relacionou bem com a mãe e aos dezesseis anos teve que sair de casa. Não pode voltar a morar com a avó que havia se mudado para local distante e atrapalharia os seus estudos. Depois de ir para casa de tios, foi morar com uma família com quatro filhos para ajudar nas tarefas escolares destas crianças e continuar frequentando a escola. Foi nesta casa que passou a "ser mesmo tratada como filha" e encontrar, novamente, o aconchego de uma família, sentimento apenas experimentado quando morou com os avós. A dona da casa era costureira e, como Rosalina era muito magra, era possível fazer roupas novas com as sobras dos tecidos. Começou, então, a se vestir melhor e também a se dedicar aos estudos. Formou-se no curso normal, foi professora e recebeu prêmios como melhor professora no município em que trabalhava.

A dificuldade com a mãe jamais esmoreceu. "Comecei a fazer sucesso, mas ela nunca, nunca, notou...fui a primeira aluna do colégio, desfilava, fui escolhida para levar flores pro governador, que eu era a primeira, nada disso valeu a pena. Pra ela". A memória familiar jamais é simples ou descreve um modo único de pertencimento e de diferenciação. Remédio e veneno alimentam nossas lembranças das relações familiares (Muxel, 2002, p.9). Filha "não desejada", acredita ser esta a razão da rejeição da mãe. Mas, como assinala em alguns momentos, sobreviveu e está aqui e gostaria muito de não ter passado por "alguns pedacinhos", mas diz que é feliz.

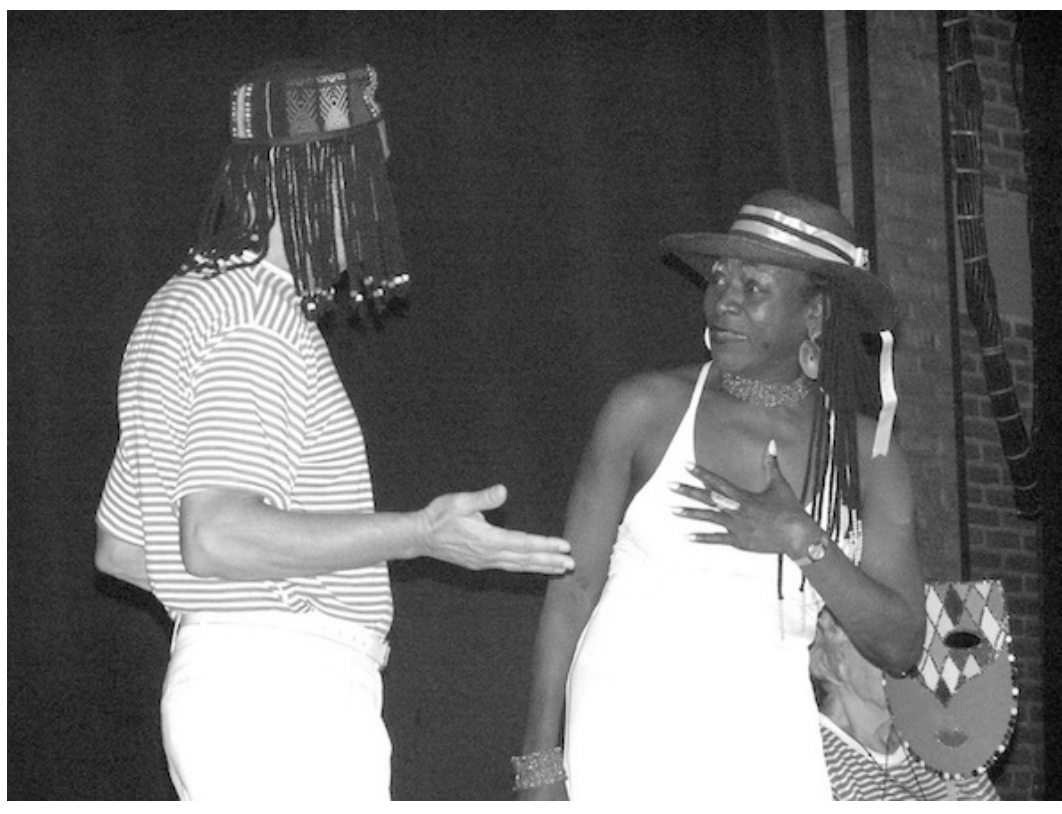

Imagem 4 - Boneca de piche

14 Esta cena faz parte da peça Monólogos de muitas vidas (2001), texto construído com relatos escritos de memória dos participantes do grupo. Os diversos relatos foram reunidos formando a história de uma única vida. Esta é uma lembrança de uma das participantes que foi escolhida, na escola, para declamar um verso sobre uma boneca. Deveria ir vestida de boneca, mas só tinha sapatos de pano para calçar. 
A segunda foto escolhida mostra a beleza e a sensualidade como uma característica marcante em sua vida, reconhecida por ela e por quem a rodeia. A luta cotidiana não impediu Rosalina de exibir, em todos os espaços, seu carisma, o cuidado com os trajes e os penteados "[...] no mundo do samba eu sou até hoje a mulher charme de Niterói/São Gonçalo". A fotografia capta uma cena em que ela pode mostrar esta beleza e é disto que ela comenta.

E esta cena com a boneca de piche ${ }^{15}$, eu me sinto totalmente uma boneca bonita com muitos portugueses a minha volta, me desejando, sinto que sou admirada por quem me olha. Então, eu me sinto mulher, me sinto atraente. Por isto, esta boneca de piche levanta o meu astral totalmente.

No ambiente do samba, tratou com cuidado de sua trajetória e sempre desfilou como destaque. Foi capa de revista no carnaval de Niterói e recebeu muitos títulos. E é assim que se reporta a terceira foto.

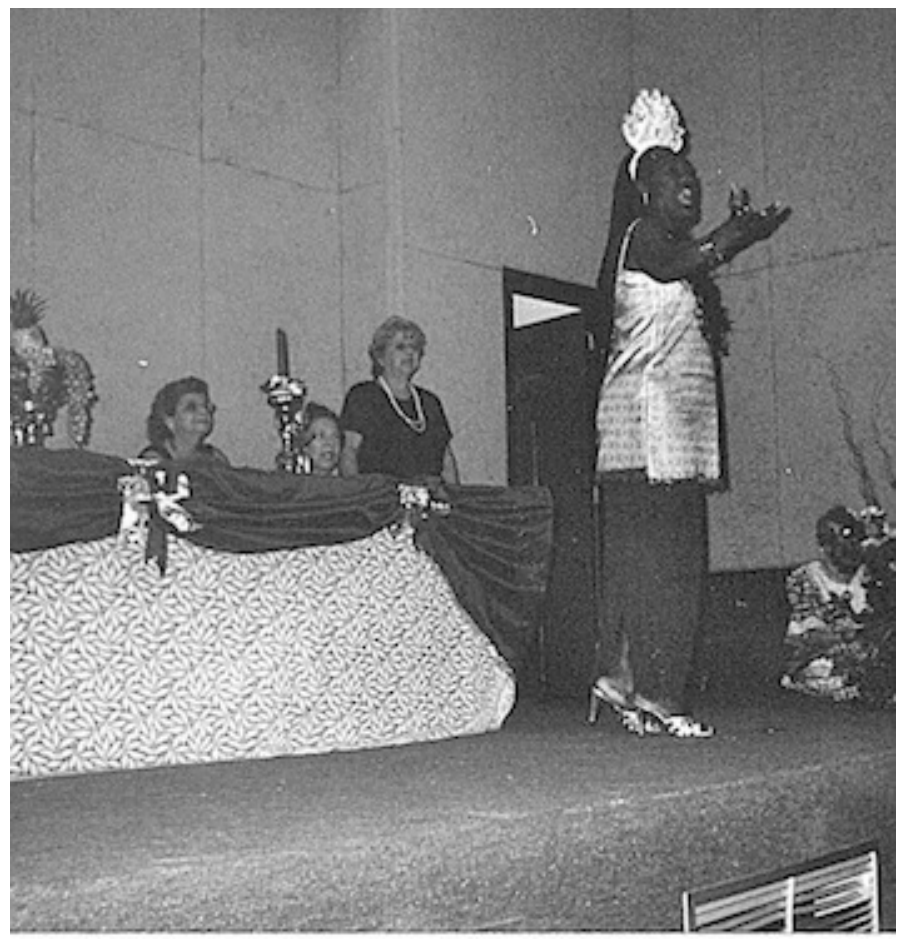

Imagem 5 - Festa para o rei negro

Esta aqui, a cena em que eu canto Festa para o rei negro ${ }^{16}$, foi uma época em que eu estava totalmente feliz, no esplendor mesmo. Eu já era do samba, mas foi através do teatro que eu comecei a voltar e a aparecer, a cantar, a fazer serestas, a fazer aquilo que eu gosto de fazer. Voltei a ficar feliz. [e se refere a foto seguinte, explicando a sua escolha] E por isto, escolhi esta outra, eu cantora no programa do Chacrinha.

15 Cena extraída da peça Niterói de nossas lembranças (2007). A cena se passa no Cassino Icaraí. O apresentador do show chama Grande Otelo e Aizita (representada por Rosalina) que cantam Boneca de Piche, de Ary Barroso e Luiz Iglesias.

16 Cena extraída do texto Monólogos de Muitas Vidas (2001), em que uma das mulheres diz que quando escutou a música "Festa para o Rei Negro" sentiu vontade de vencer e ser rainha. 


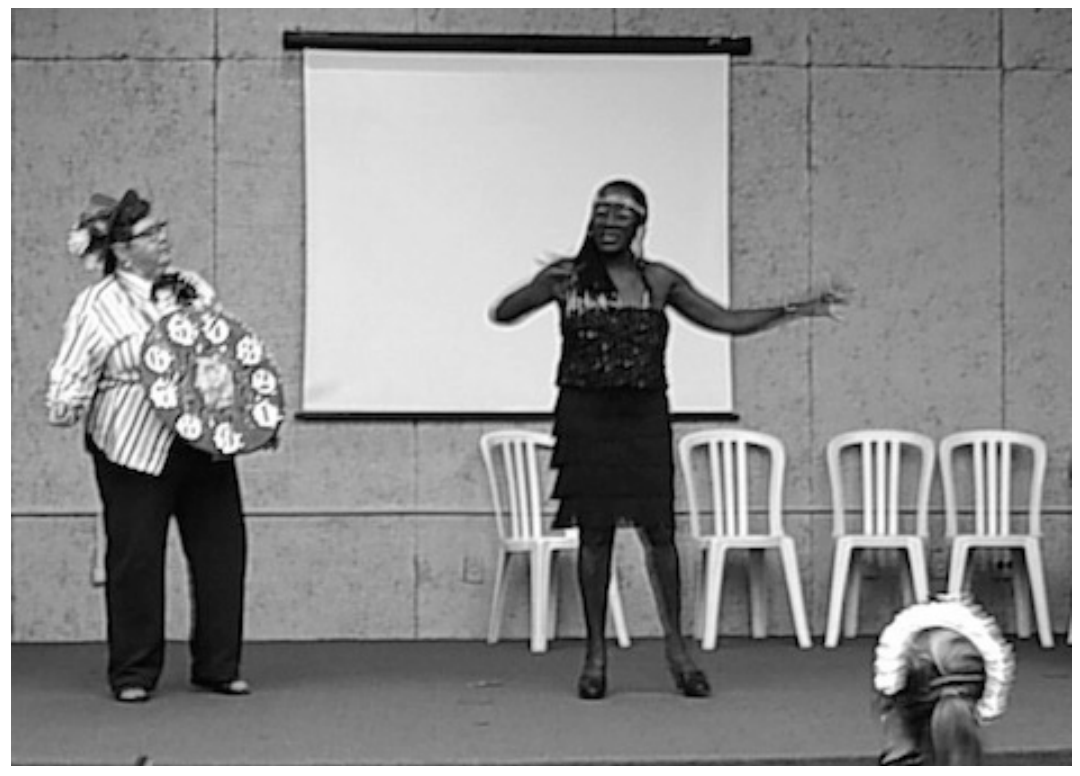

Imagem 6 - Programa Chacrinha

A participação na Oficina de Teatro aparece como uma possibilidade de projeção em outros espaços, uma maneira de espantar a dor, "nem sei explicar o que sinto quando estou ali no palco, interpretando. Foi ali que eu comecei a despertar para a vida. Não tenho mais tristeza dentro de mim. Apesar de sofrer, de passar por momentos que todos nós temos".

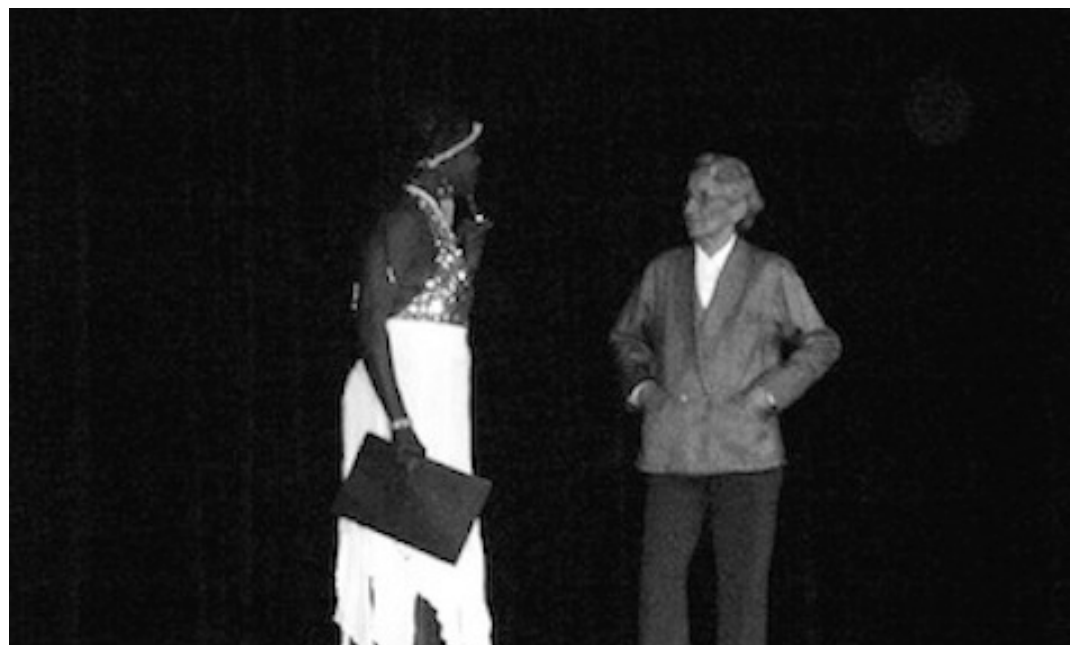

Imagem 7 - Barrada na portaria

O espaço da oficina torna-se também lugar de reflexão sobre preconceitos, direitos e modos próprios e coletivos de enfrentamento. "Esta foto aqui, apesar de falar do preconceito ${ }^{17}$, me dá um orgulho tremendo de fazer. E é assim que eu me sinto agora, forte, realizada, enfrentando os preconceitos. Então, eu me sinto mais alguém. Mesmo diante de quem me desprezou".

Rosalina mapeou sua vida com base nestas cinco fotos, arrumou as lembranças e organizou o seu discurso procurando dar sentido e coerência aos fragmentos de

17 Cena extraída do texto Nós no tempo! (2003), em que uma mulher negra é impedida de entrar em um prédio pelo elevador social. A cena é baseada em relato da própria Rosalina. 
memória. Coerência e continuidade são elementos fundamentais na construção da identidade (Pollak, 1992). A possibilidade de olhar para trás, provocada pelas cinco imagens, trouxe para o seu discurso a ideia de resistência, presente desde o seu nascimento.

\section{Os extremos de Eunice}

Eunice perdeu a mãe aos dois anos e foi criada pela avó. Com o falecimento de sua avó, quanto tinha dez anos, passou a morar em casa de parentes, mudando daqui para ali, pois nenhum deles se considerava responsável por ela.

Enquanto minha avó viveu a gente era pobre, mas pobre que nem Jó, mas eu era feliz. Eu me lembro que brincava muito, minha avó não me batia, eu ia para a escola. Então, enquanto minha avó foi viva eu fui feliz, depois que ela morreu, aí é que a coisa ficou feia.

Não lembra até que série estudou, mas gostava muito de ler histórias em quadrinhos, lia as folhas de gibi que embrulhavam as compras da quitanda. "Aprendi a ler e escrever, claro que não tenho uma escrita perfeita, não tenho formação nenhuma, mas como eu gostava muito de ler, aprendi assim, depois pelo rádio, pela televisão, sempre gostei dessas coisas, de saber, de ouvir". Conta que mais tarde aprendeu muito com os filhos. É, como ela mesmo diz, uma autodidata. Meio poeta, quando mostra uma fotografia e afirma "esta aqui é bem antiga, acho que eu não tinha chorado ainda", meio "avó paina" de Jorge Andrade ${ }^{18}$. Um de seus relatos de lembrança presente no texto Monólogos de muitas vidas, conta sobre o jeito da avó fazer café "moído e coado" e do cheiro que nunca conseguiu esquecer.

Aos quinze anos fugiu com um homem dez anos mais velho que foi o seu marido durante toda a vida e com quem teve nove filhos. Quando conheceu o marido, aos catorze anos, já trabalhava como babá.

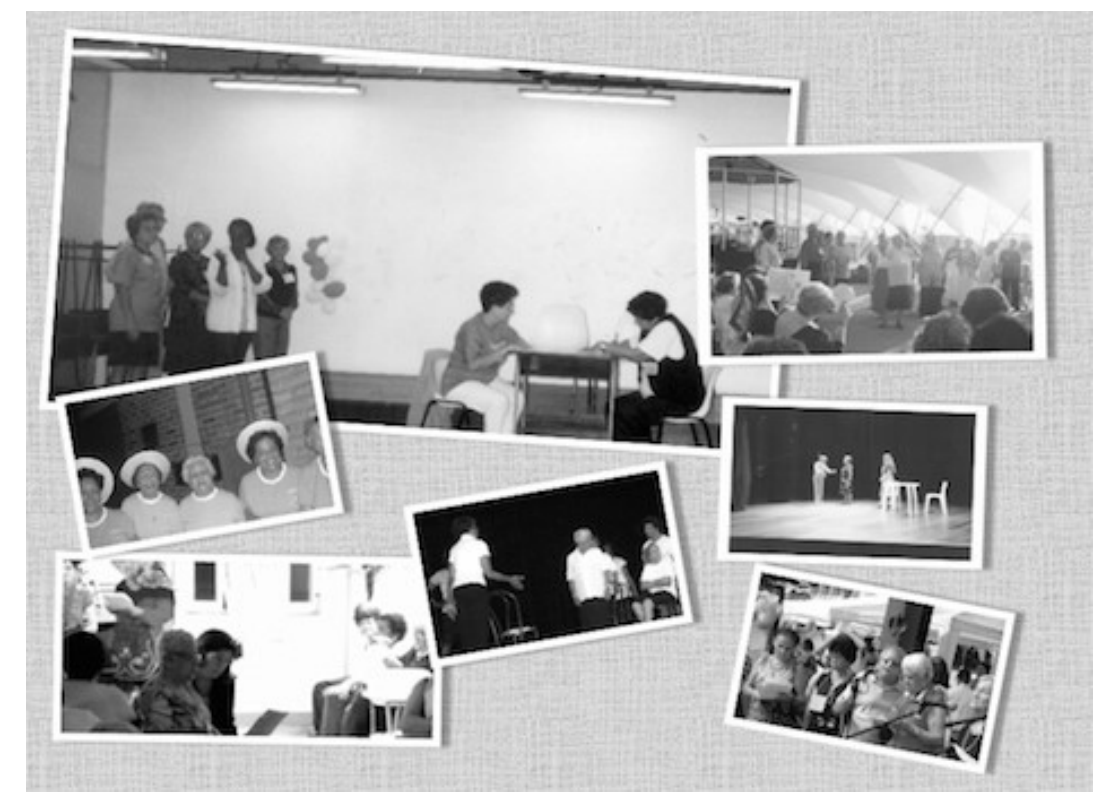

18 "não chorando, chora constantemente: de seus olhos não caem lágrimas, descem saudades [...]". (Andrade, 1978, p.105) 


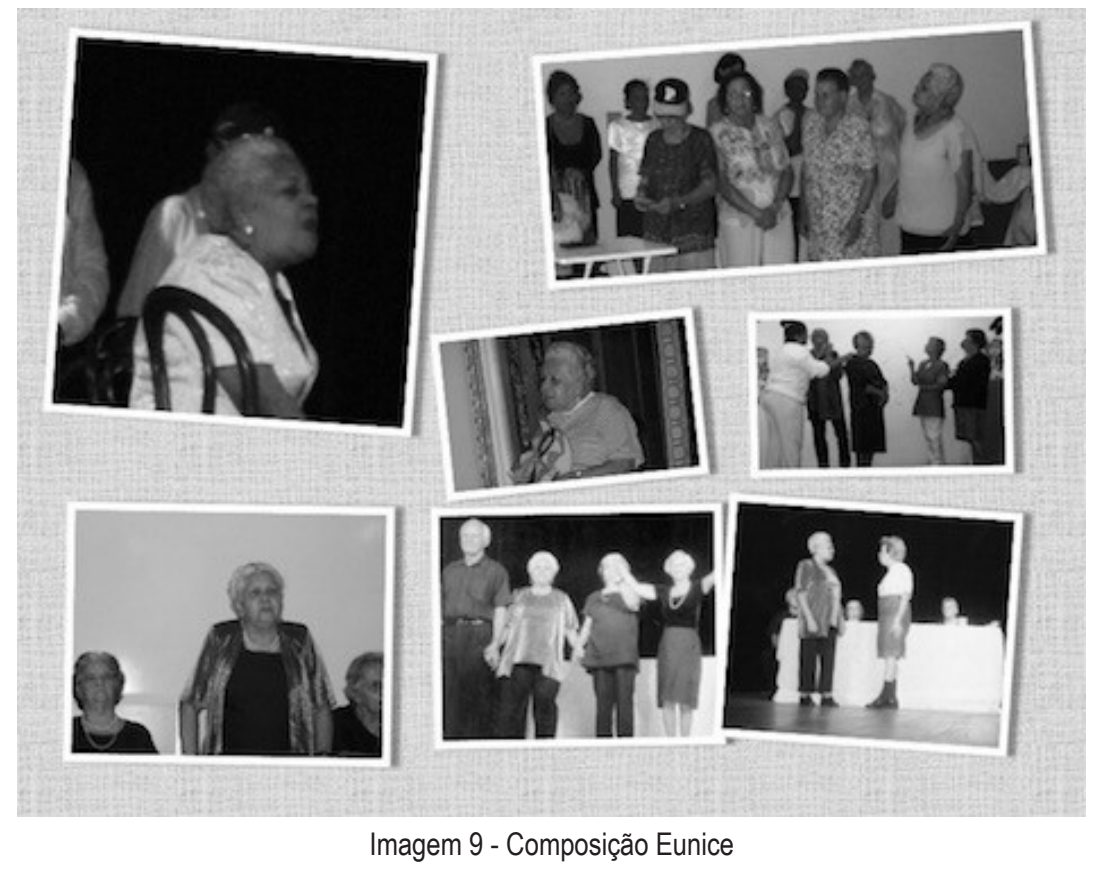

Durante a entrevista, realizada em maio de 2015, Eunice relutou em dar uma ordenação às cinco fotos, apesar de as ter selecionado com relativa tranquilidade. $O$ modo como as ordenou privilegiou os extremos, escolhendo a primeira e a última. Ou seja, como era antes, no "tempo da tristeza", e como é agora, quando é possível "rir e fazer rir". Depois foi preenchendo as fotos do centro.

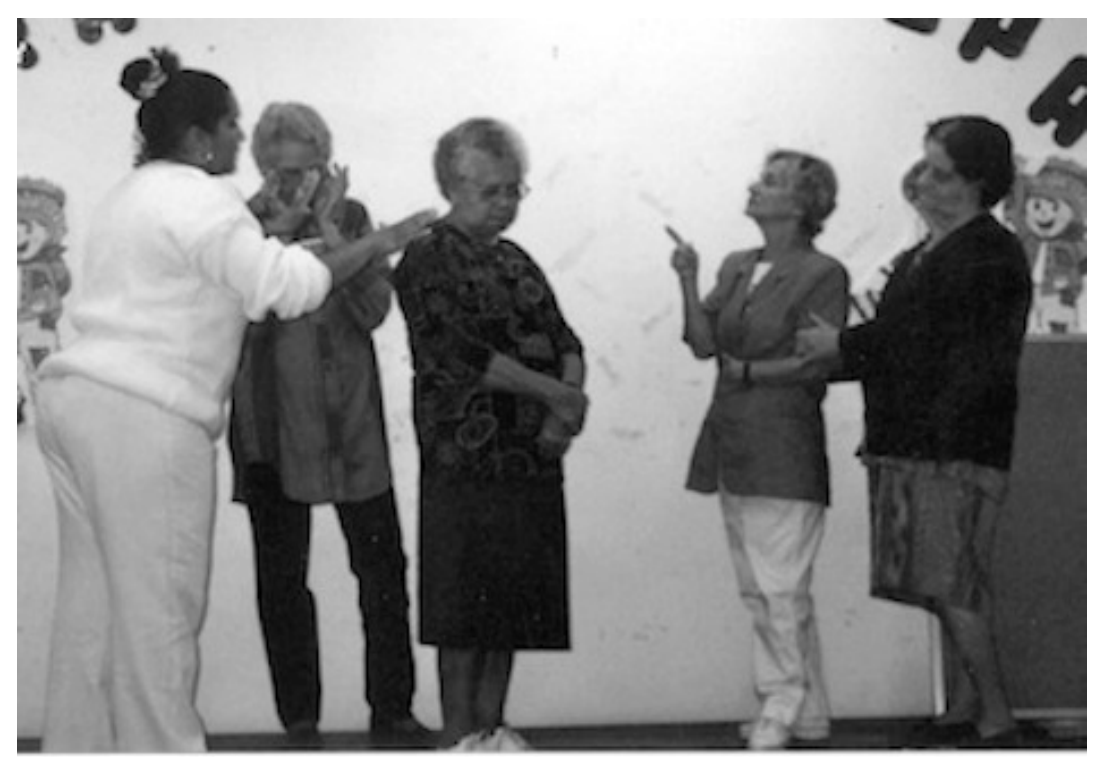

Imagem10 - Família no passado

A foto que mais me chama atenção, que mais mexe comigo é esta aqui ${ }^{19}[$ referindo-se a primeira foto], eu acho que sou um pouco assim, triste. Eu vivo muito apegada ao passado. A minha infância me marcou muito, não tive mãe, não tive pai, fui criada pelos outros, na adolescência também foi ruim. Depois que me

19 Imagem 10 - Cena de um exercício de Oficina, preparação para o espetáculo Sonho de Glorinha (2000). É uma imagem criada pelo grupo representando um tipo família do passado. 
casei é que comecei a viver, a me sentir segura, fui mudando. [...] Porque eu tinha alguém que cuidava de mim, que gostava de mim, se importava. Era o meu porto seguro [...] Acho que Deus botou Marino na minha vida já para tirar aquela coisa ruim da infância. [...] Então, esta foto me leva para tempos muito longe, lembra os dias de tristeza, de amargura, o tempo que eu não queria viver.

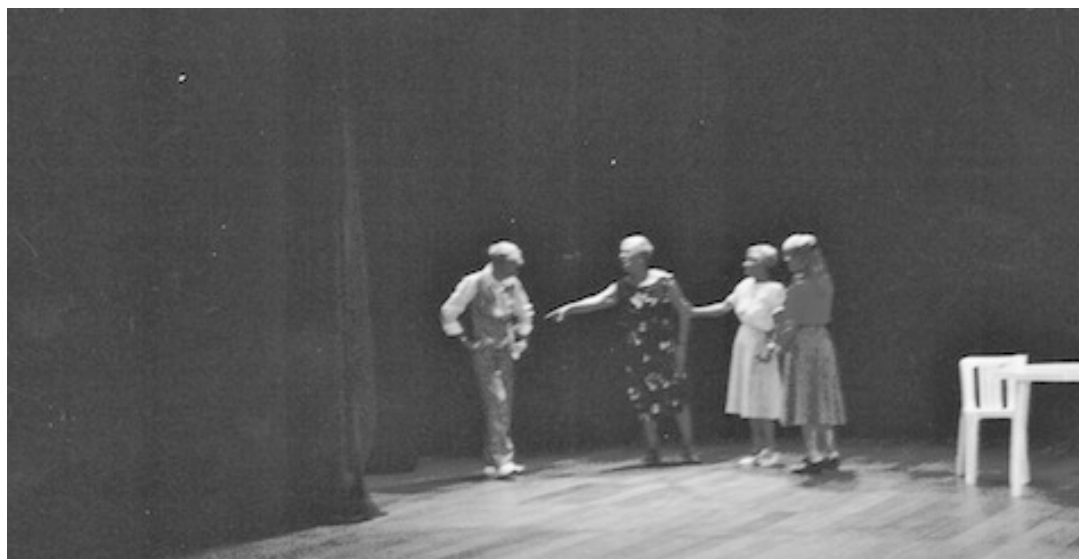

Imagem 11 - Avó e o genro

Referindo-se a última foto na ordenação final, comenta "Esta aqui20, é o que estou hoje, porque sempre fui um pouco triste, eu não me achava engraçada, mas eu gosto do humor. Hoje eu sou capaz, ou um pouco mais capaz, de fazer graça". Conta que hoje é "uma velha feliz". O que lhe faltou na infância e adolescência, ela tem de sobra agora, a liberdade. "Liberdade é uma coisa muito boa. Depois que minha avó morreu, eu tinha dez anos, não tive mais liberdade, sempre vivendo em casa de parentes. Quando casei, meu marido era muito ciumento. Era boa pessoa, bom marido e bom pai, mas ciumento".

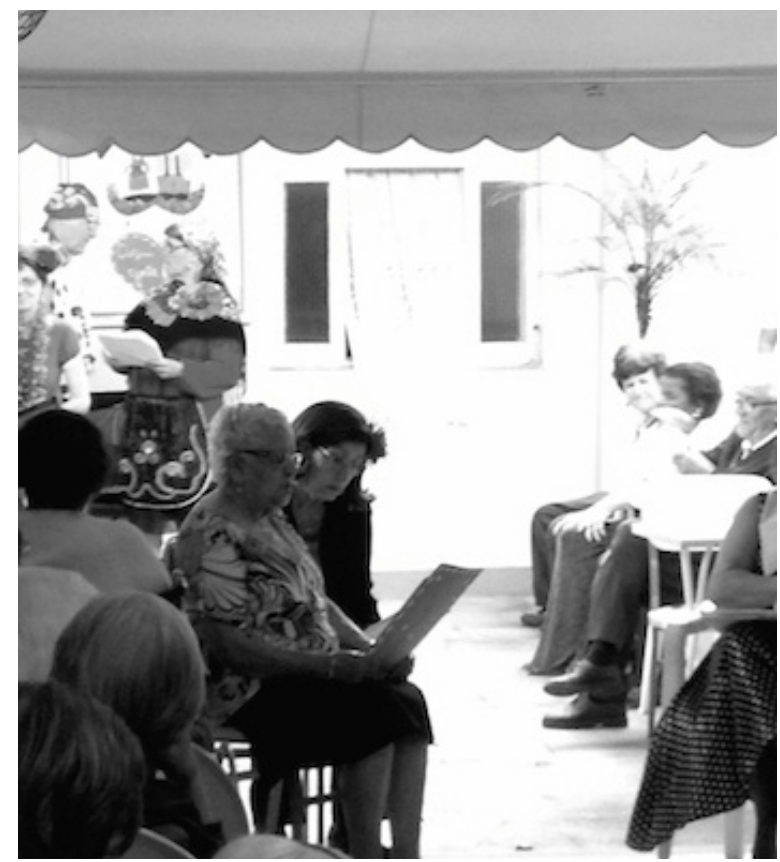

20 Imagem 11 - Cena extraída do texto Sonho de Glorinha (2000). A cena se passa na sala da casa de Glorinha, uma jovem dos anos 1940 que sonhava em ser atriz. Eunice faz o papel da avó de Glorinha, que enfrenta o genro em defesa da neta. Mas faz isto com muito humor, deixando o pai da jovem totalmente desconcertado. 
Imagem 12 - Avó e neta

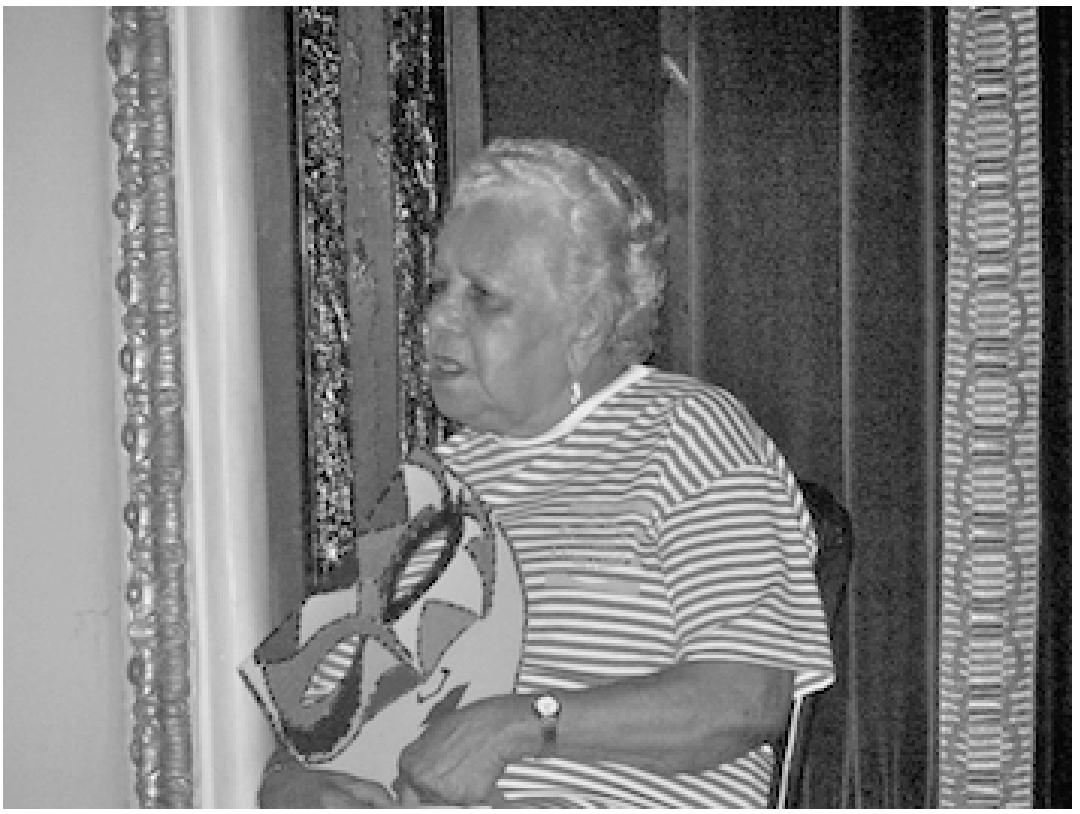

Imagem 13 - Narradora

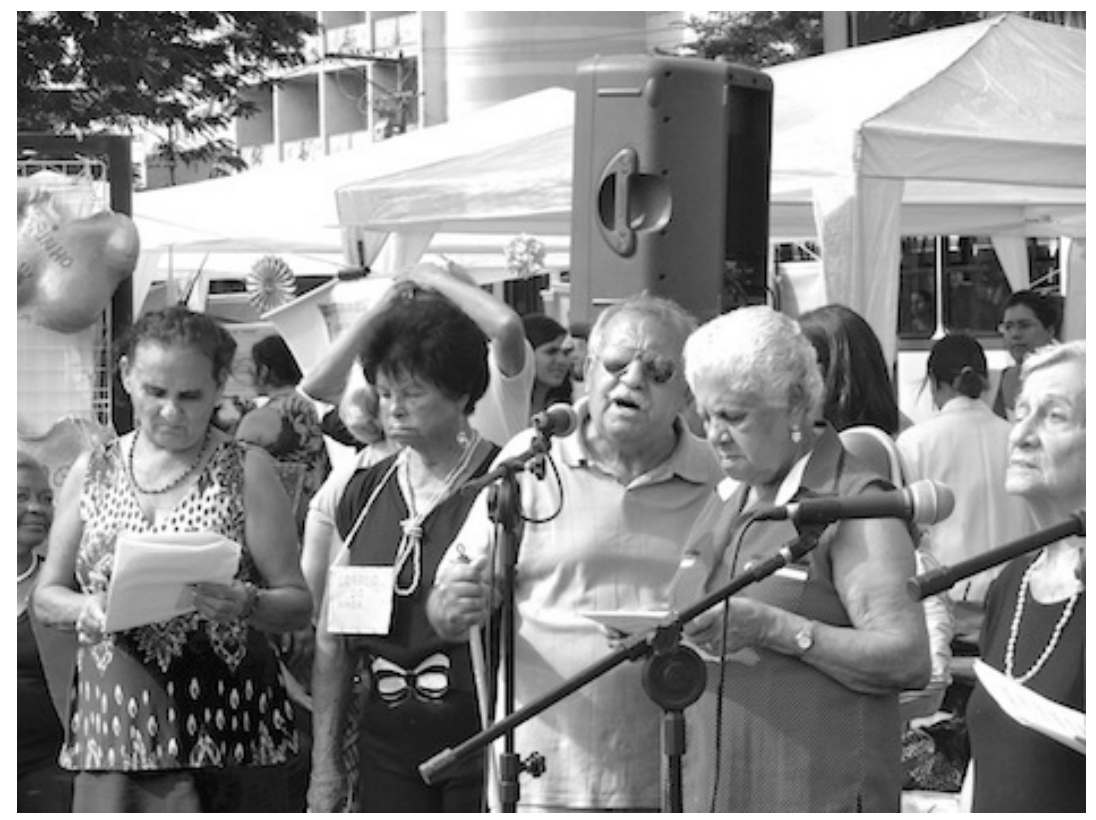

Imagem 14 - Novela de rádio

E, então, comenta as outras três fotos que ficaram no centro de sua sequencia. "Esta outra foto aqui ${ }^{21}$ eu já estava bem melhor, não me traz tristeza não. Eu já estava aqui há muito tempo". Conta que quando chegou na oficina de teatro, estava "caindo aos pedaços". Quando perdeu o marido foi como se "o mundo tivesse caído. Ele era meu tudo. [...] Foi muito difícil ficar sem ele". E continua, "estas outras fotos ${ }^{22}$

21 Imagem 12 - Cena extraída do texto Niterói de nossas lembranças. (2007). Avó conversa com a neta e conta uma lembrança de seu tempo de juventude sobre os bailes de carnaval em um clube da cidade.

22 Imagem 13 - Cena extraída do texto A cena é nossa! (2007). Cena final, em que uma das narradoras (representada por Eunice) se dirige à plateia e conta sobre os acontecimentos políticos e culturais pelos quais passou. Imagem 14 - Cena extraída da peça Radio Avançado no Ar! (2009), que trata da Era do Rádio contada com lembranças dos participantes do grupo. $O$ locutor chama os comerciais e em seguida anuncia mais um capítulo da novela Corações Partidos. Eunice faz a mocinha romântica, Cintia Celeste. 
também eu estou bem, parecida com o que estou hoje" (refere-se a terceira e quarta fotos). Relata que aos poucos foi melhorando, já tinha a companhia das parceiras da oficina. Em vários momentos se refere aos aprendizados nos espaços de sociabilidade que frequentou e frequenta e a possibilidade de ir onde quiser, de ter a casa e as contas organizadas e poder receber amigas. Aos noventa anos, com família grande e atenciosa, mora sozinha. É a sua liberdade.

\section{Gabriela e a memória afetiva}

Gabriela nasceu em 1921, em uma família extensa chefiada pela avó materna. Filha caçula, com duas irmãs, moravam todos com esta avó. Família de artistas, os pais se conheceram em um grupo de teatro amador. $O$ pai trabalhava em comércio, mas quando ela nasceu estavam numa fase difícil financeiramente. Impetuosa e determinada, estudou contra a vontade do pai e se formou no curso normal. Casou em 1945, exatamente no dia da vitória dos aliados na Segunda Guerra. Conta que quando voltou do casamento, ao entrar em casa na companhia do marido, ouviu os fogos. Então, ligaram o rádio e ficaram sabendo do fim da guerra. Teve seis filhos e, na contramão dos relatos de viúvas sobre os casamentos, diz que foi muito feliz com o marido. Trabalhou como professora e diretora de escola, foi militante de sindicato dos professores e ajudou a fundar o SEPE (Sindicato Estadual dos Professores de Educação do Rio de Janeiro), núcleo de Niterói. Participou da histórica greve de 1979 e por esta razão foi demitida do cargo de diretora. Foi chamada para depor na polícia e "o delegado perguntou se eu tinha recebido pressão para fazer greve e fechar a escola. Disse para ele que eu tinha decidido fazer a greve porque acreditava na luta do sindicato. Eles queriam que eu desse uma lista dos grevistas. Claro que não dei". Os estudantes, professores e funcionários da escola, quando souberam da demissão, fizeram uma caminhada até a sua residência para manifestar apoio.

Esteve presente na passeata dos professores, em 1988, quando ofereceram flores para os policiais e cantaram a música de Geraldo Vandré, Pra não dizer que não falei de flores. Esta é uma lembrança de Gabi presente em um dos nossos textos ${ }^{23}$. Em 2014, participou de mesa sobre Gestão Democrática e foi homenageada pelo SEPE/ Niterói em Seminário de Educação ${ }^{24}$ em razão de sua coragem durante os anos em que participou do movimento dos professores.

Na minha casa, a palavra medo não existe. Este medo de dizer o que pensa, de se posicionar, de enfrentar os poderosos não existe mesmo. Meu marido também era assim, não tinha medo de nada e ensinou isto aos meus filhos. Este medo nunca esteve presente na minha família.

Faz teatro amador desde que os filhos cresceram. "Quando meus filhos cresceram, foram fazer teatro. Então, eu disse para mim mesma e para o meu marido, está na hora de voltar!". Assim como Eunice e Conceição, participa da Oficina de Teatro e

23 Um boteco e suas histórias (2004). O texto trata dos acontecimentos políticos e culturais das décadas de 1960 e 1970 que ficaram na memória do grupo e a relação deste período com as suas vidas.

24 Seminário de Educação do SEPE Niterói, realizado em 22 de outubro de 2014, na Universidade Federal Fluminense. 
Memória desde o início, em janeiro de 1999. Privilegiada com um corpo magro e forte, enorme expressividade, dança e canta nas apresentações do grupo. Idade nunca foi empecilho para fazer qualquer exercício nas oficinas ou dançar tango em uma das apresentações. Com memória e disposição impressionantes, costumava decorar o texto inteiro, pois se alguém faltasse no dia da apresentação poderia substituir.

Comemorou seu aniversário de noventa e três anos com uma apresentação do Radio avançado no ar, em outubro de 2014, em um pequeno teatro construído na casa de uma de suas filhas. Uma oportunidade para que a família, com inúmeros artistas, cantores e músicos, pudesse assisti-la.

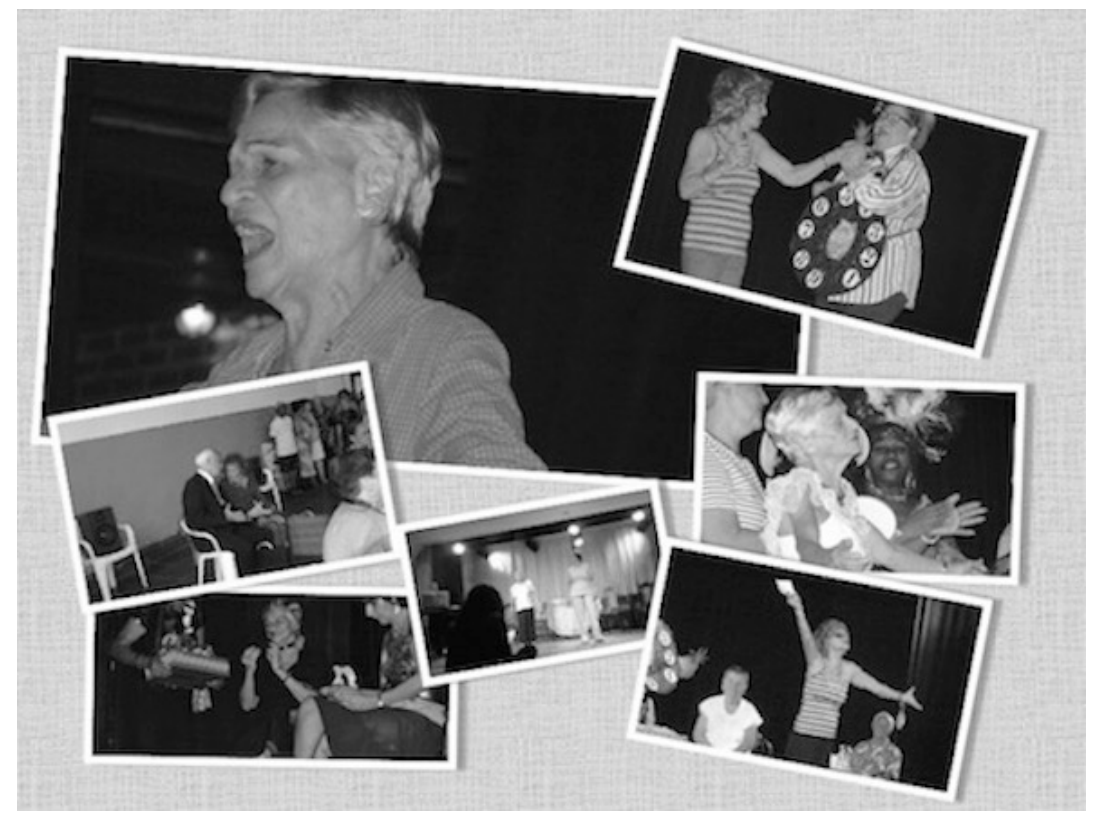

Imagem15 - Composição Gabriela

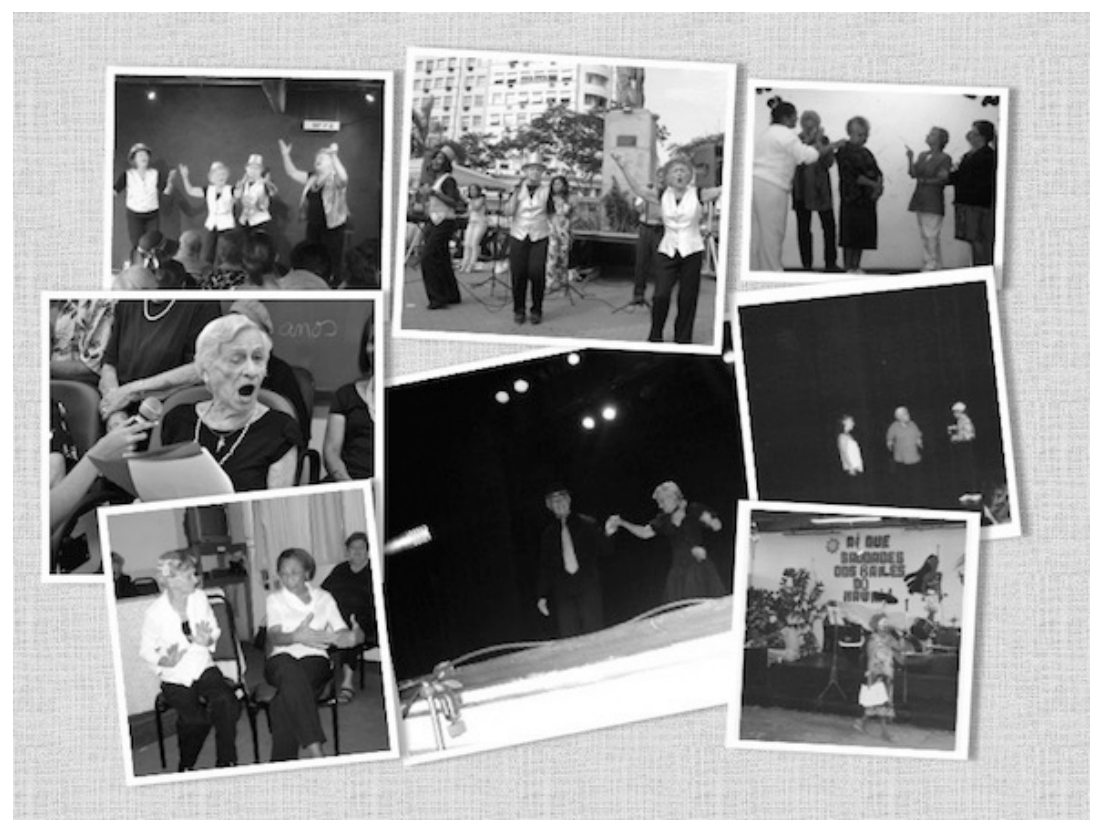

Imagem 16 - Composição Gabriela

Dona de belíssimas imagens cênicas, graças a sua expressividade e carisma no 
palco, foi difícil fazer a seleção das quinze fotos iniciais. O que descartar? Comecei a entrevista espalhando as fotos sobre a mesa, mas Gabriela segurou todas juntas, fez um pequeno leque em suas mãos e comentou as apresentações. Pedi as fotografias e novamente distribui as imagens embaralhadas, explicando que era interessante olhar o conjunto para depois separar as cinco. A escolha seguiu o mesmo jeito impetuoso que a caracteriza. Confesso que tentei mostrar a beleza das imagens, mas Gabi, como é conhecida por todos, de modo decidido selecionou as fotos rapidamente.

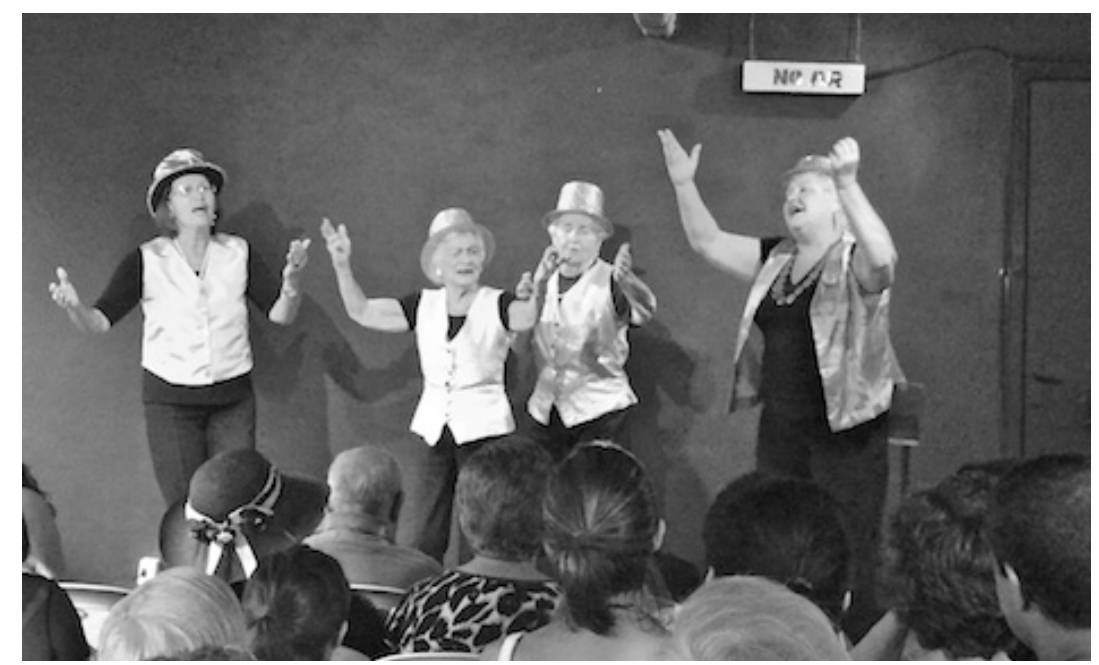

Imagem 17 - Apresentação no aniversário

A primeira fotografia ${ }^{25}$ escolhida é simbólica. Foi a apresentação, em 2014, realizada para a sua família e convidados, no pequeno teatro da casa da filha. A comemoração de seus noventa e três anos, portanto, dia de grande significado para ela. Disse que escolheu também porque é uma peça que faz muito sucesso e que todos adoram lembrar da era do rádio.

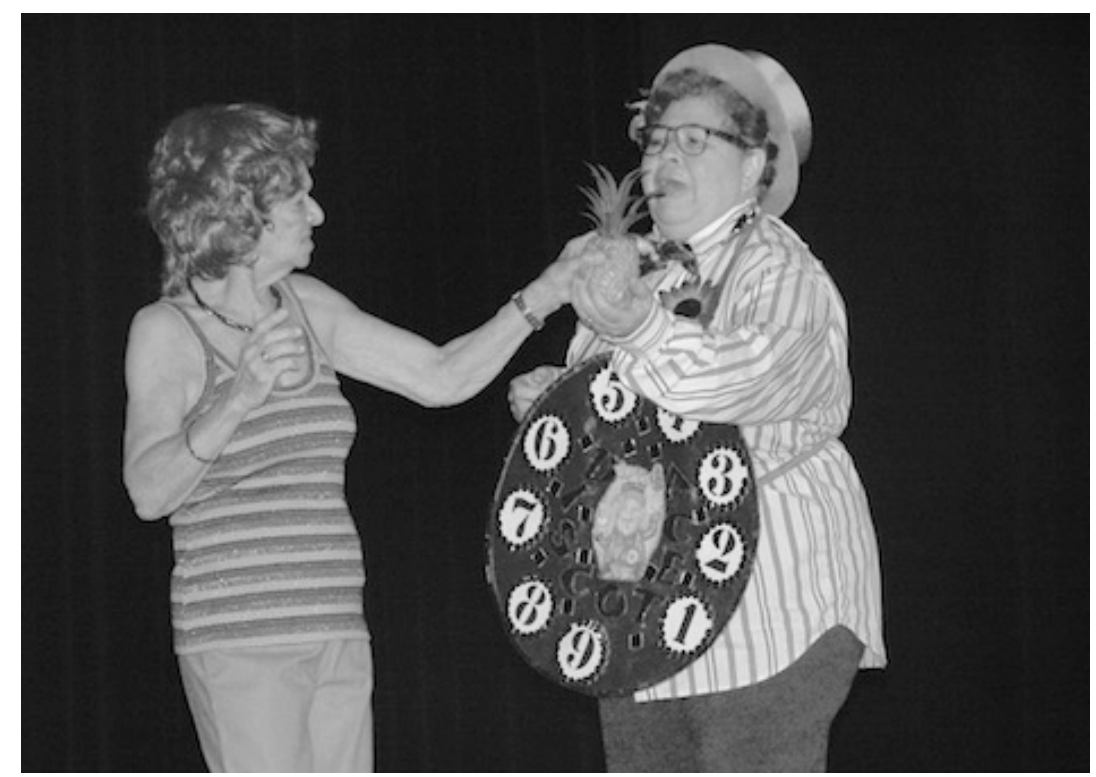

Imagem 18 - Show de calouros Chacrinha 
Sobre a segunda ${ }^{26}$ imagem, afirmou que adorava o programa do Chacrinha e costumava assistir com freqüência. A foto é de um momento do programa, o show dos calouros, lembrança que o grupo trouxe para o texto. Gabi representa uma das calouras que fracassa e recebe a buzinada e o troféu abacaxi. A cena, em todas as apresentações, foi hilariante, porém para ela o que a imagem acionou foi pensar nas tardes em que assistia ao programa de televisão, em casa, junto aos seus familiares.

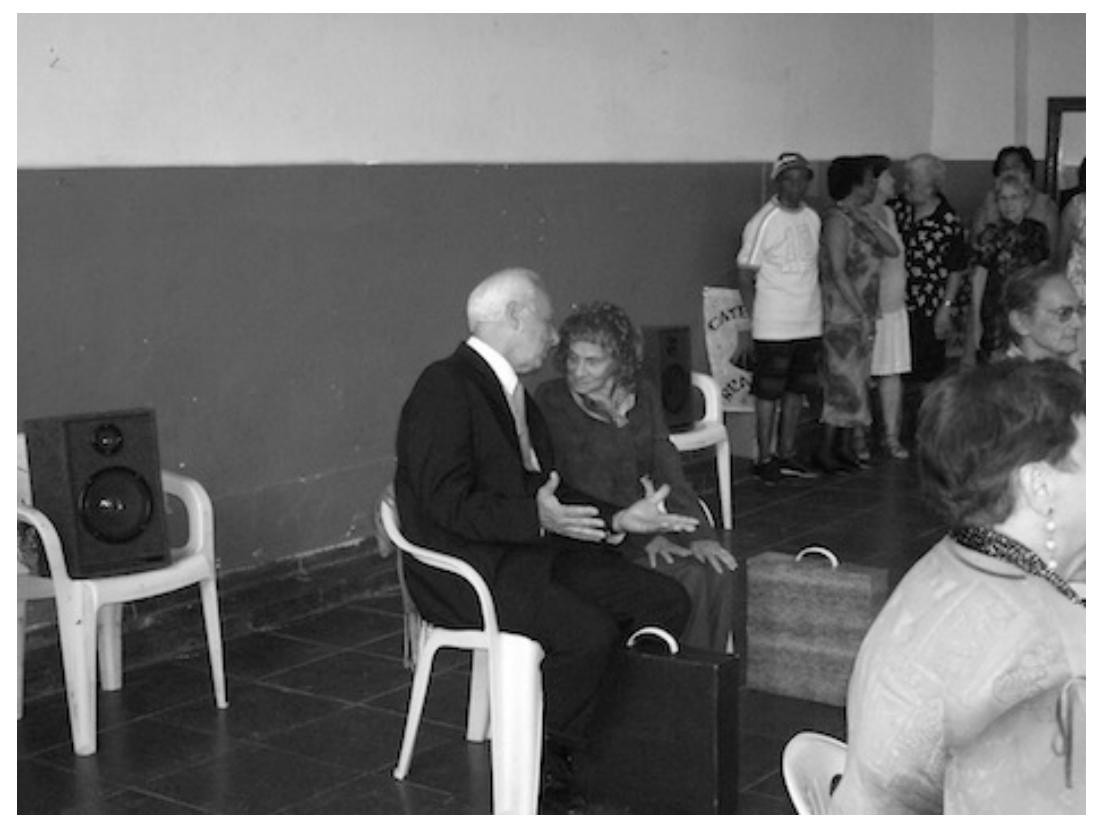

Imagem 19 - Cena no ônibus

A terceira foto ${ }^{27}$ mostra outra cena cômica, desta vez no texto Andanças de um viajante. A escolha de Gabi não se deu exatamente pela graça e comicidade da cena ou pela sua atuação, mas porque "lembro das viagens que fiz na minha vida".

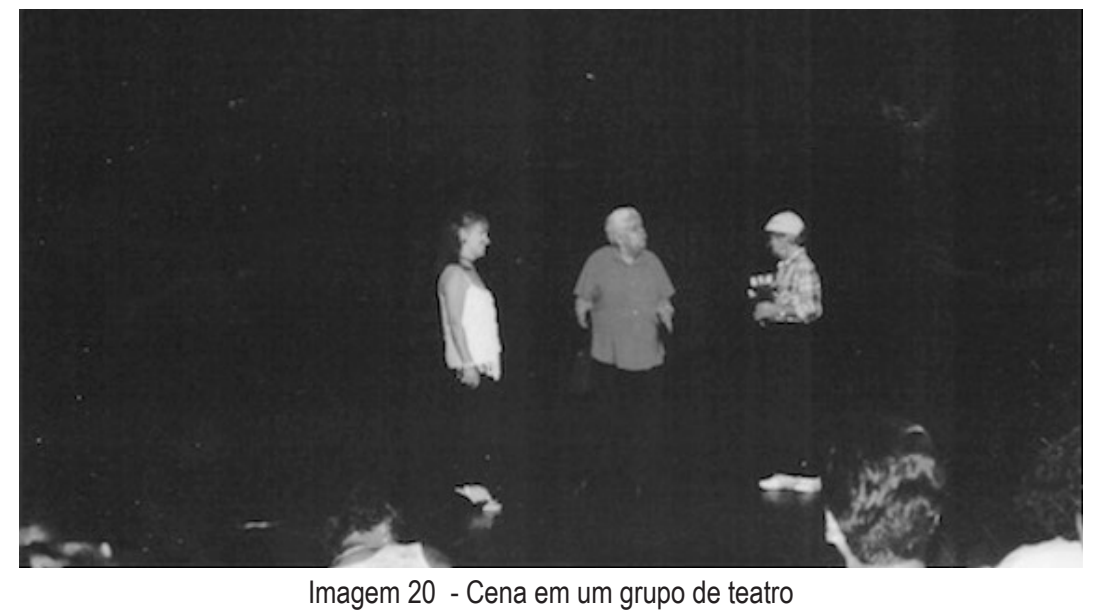

A imagem seguinte ${ }^{28}$ também se refere a uma cena cômica, e foi por esta razão que ela diz ter escolhido. "Foi uma piada muito boa, todos acham muita graça”. Esta 
foi uma lembrança da própria Gabi, em uma se suas experiências com outros grupos de teatro que participou, quando o diretor pede ao jovem para fazer uma declaração para a moça e ele usa uma comparação infeliz, dizendo que gostava dela tanto quanto de seu prato de comida predileto, bucho com batatas. Gabi, que representou o jovem, traz para a cena o tom inocente presente na declaração e imprime enorme comicidade à cena.

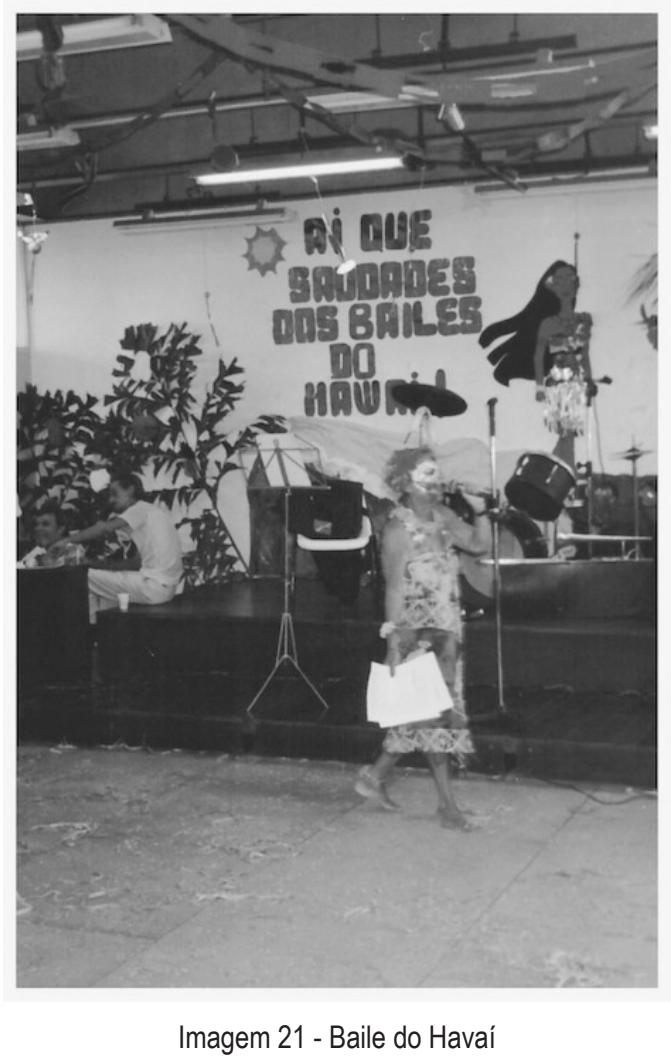

A última foto ${ }^{29}$ escolhida foi exatamente a primeira apresentação que fizemos. $O$ roteiro foi escrito por ela, uma das razões da escolha, e a história era sobre encontros e desencontros de um casal em bailes de carnaval em um intervalo de dez anos. Uma lembrança que revela uma história romântica, com nuances de folhetins e novelas de rádio.

Gabi poderia ter escolhido as fotos impactantes, as que carregam no tom dramático da interpretação, presentes no conjunto das quinze fotos. Seu modo de interpretar as personagens, seus relatos de memória escrita e mesmo sua narração oral, muitas vezes, beiram ao épico. Ricas em detalhes, suas histórias hipnotizam ouvintes, graças a sua capacidade de contadora. No entanto, ao proceder a escolha das cinco fotos, poderíamos dizer que ela se dirigiu ao significado afetivo das imagens e a maneira como estas imagens a fizeram mergulhar em si mesma.

\section{Conceição e o start de lembrança}

Conceição nasceu em 1927, casou com dezesseis anos e teve dez filhos. Com três anos perdeu a mãe. Mesmo com uma "madrasta má", afirma várias vezes que 
teve uma infância muito feliz, "aquele tempo que criança não tinha ambição com nada, então, tudo que a gente tinha era motivo de festa". Com pai e madrasta não podia conversar, então, eram os passarinhos e as árvores suas companhias, "gostava muito de conversar, tudo que eu via eu conversava". Com sete anos, por influência da madrasta, o pai a entregou para uma família na Tijuca, no Rio, acreditando que a matriculariam em uma escola e cuidariam dela. Na verdade, foi exercer as funções de empregada doméstica, mas sem salário, "pegar cachorro, tirar pulga, limpar quintal, limpar galinheiro, ir na rua fazer compras. Colégio, nunca vi!" Aprendeu a ler observando os comentários dos patrões sobre as matérias dos jornais.

\begin{abstract}
Via aquelas letras grandes, ficava curiosa, sempre fui muito curiosa, então, eu queria saber o que estava escrito ali [...] apanhava o jornal e perguntava: que letra é esta? [...] Aí, um dia, a filha deles disse para eu ir na quitanda e comprar uma cartilha. Naquele tempo era a cartilha do povo. Cheguei, sentei perto dela e comecei a ler a primeira página, ela marcou aula para o outro dia, aí eu li metade da cartilha. Em dois dias eu li a cartilha todinha. Aí eu comecei a pegar aqueles livros que elas estudaram, tinha muitos livros, tinha um guarda-roupa cheio de livros. Eu li muita historia do Brasil, li muita geografia, aqueles livros com figuras bonitas, eu li muito.
\end{abstract}

Com onze anos voltou para casa, pois ficou doente e foi internada duas vezes. Quando o pai descobriu, foi buscá-la. A primeira vez que foi para a escola tinha doze anos, fez uma prova e foi para a terceira série, mas estudou até a quarta. Começou a trabalhar aos catorze em fábricas, nove horas de trabalho e uma hora de almoço. $O$ casamento não foi fácil, mas ela afirma que "levava o caso assim, não sei, é um dom que Deus me deu, não sei se ele disse assim, você vai ter que carregar a cruz pesada, mas você vai ter um dom de aceitar as coisas. Eu aceitei muitas coisas na minha vida". Para ela, o que vale é guardar as boas lembranças, "as lembranças que me magoavam eu fui esquecendo, fui esquecendo essas magoas, e só fui guardando coisas boas. Então, é por isso que eu sou feliz, sou muito feliz mesmo".

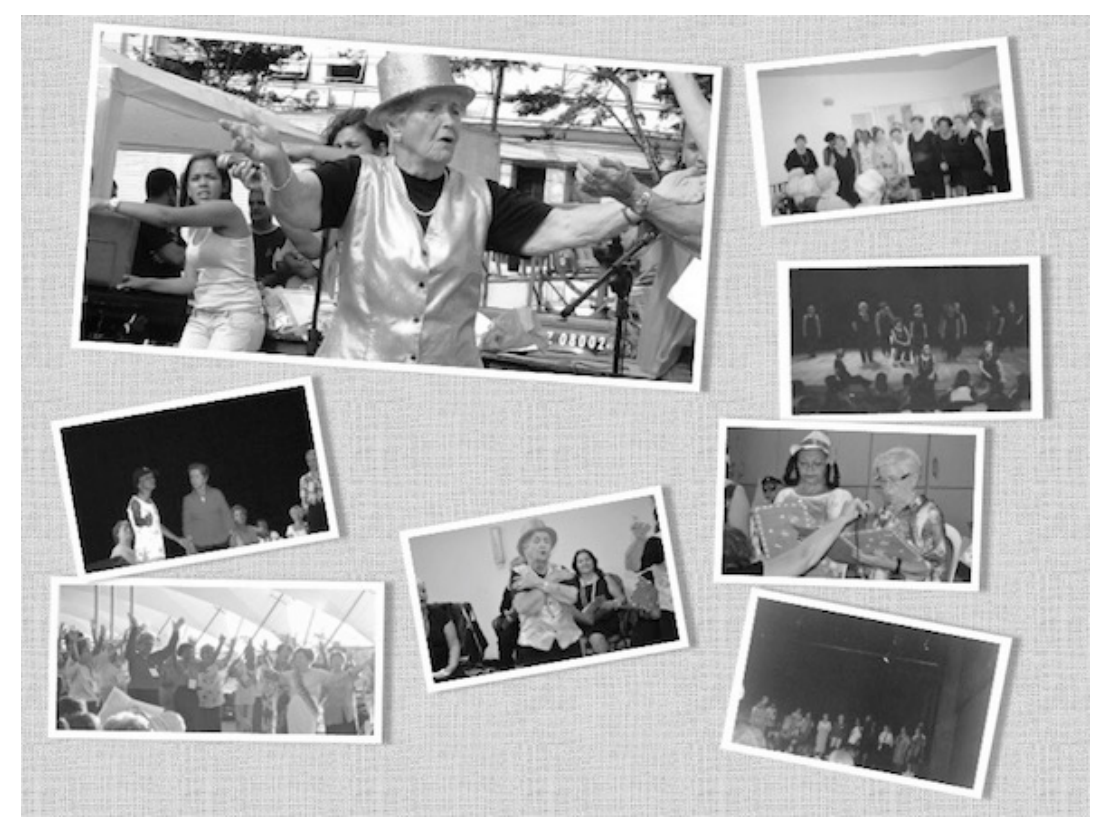

Imagem 22 - Composição Conceição 


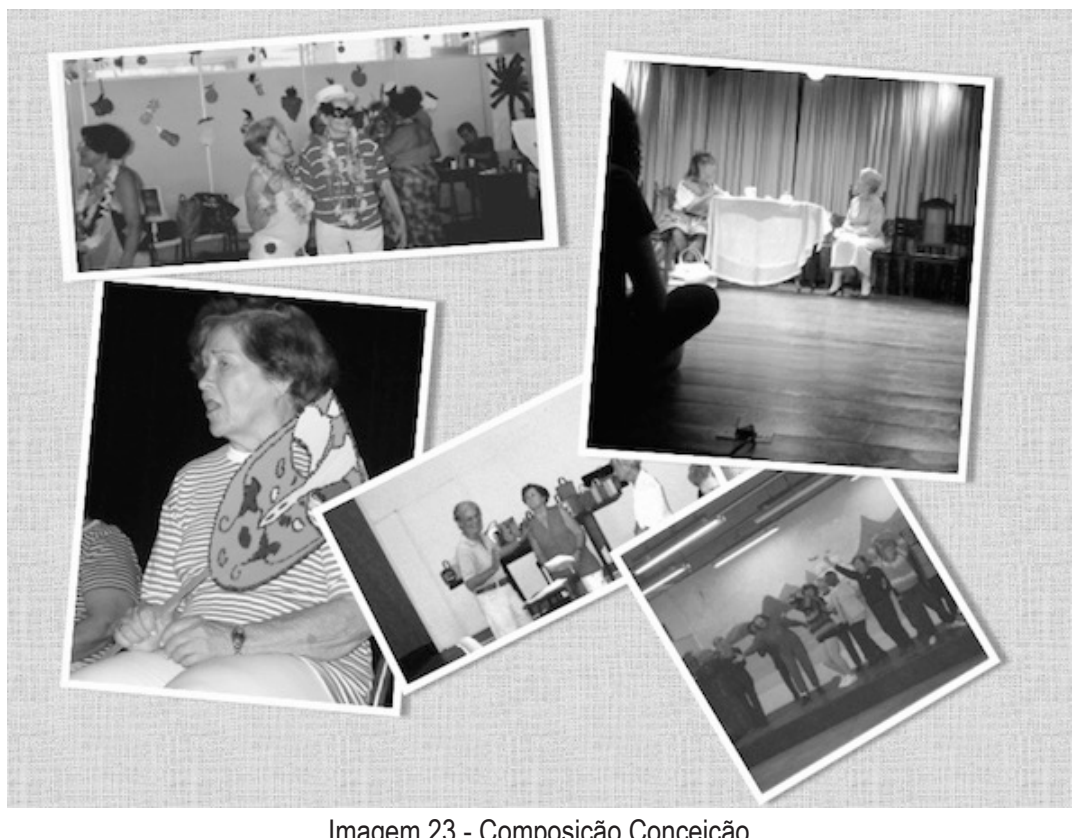

Espalhei as fotos na mesa e ela falou sobre cada uma delas, o nome da peça, o tema abordado, as personagens que ela fez, com quem contracenou, os lugares em que nos apresentamos e as pessoas que já não estão mais conosco. Conceição lembrou com detalhes de quase todas. Sem dificuldade escolheu as cinco fotografias e não teve preocupação alguma com cronologia. Seu foco recaiu sobre o valor simbólico presente na evocação provocada pela imagem. Ou melhor, as fotografias foram aqui os "starts de lembrança" e possibilitaram pensar o passado acionado pelos elementos do presente.

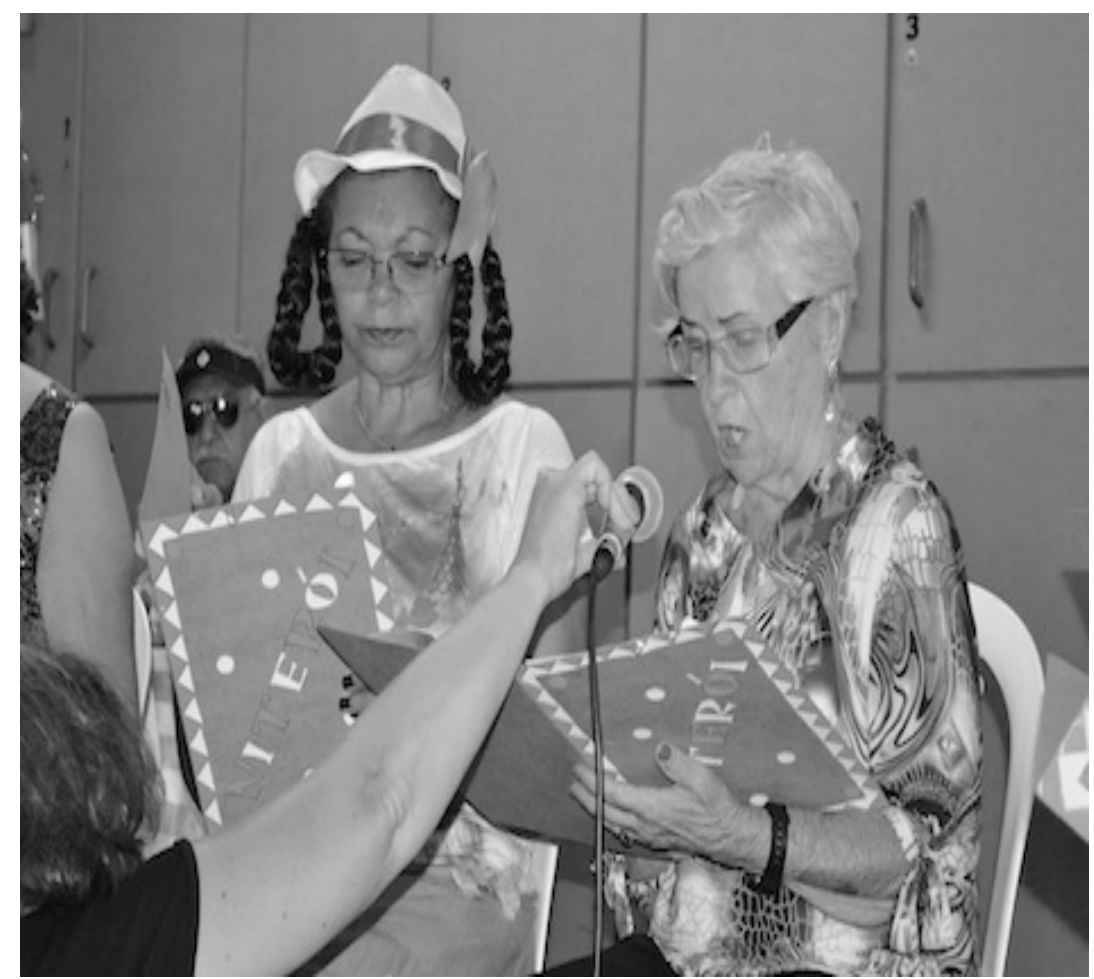


Em relação a primeira Imagem ${ }^{30}$, ela afirmou que as apresentações e o texto foram muito bons, porque trouxeram lembranças de Niterói, dos lugares, dos acontecimento, e do jeito de viver naquela época.

Fui uma criança pobre, mas aproveitei muito a meninice, a adolescência. Minhas roupas eram as que as filhas dos patrões não queriam mais [...], meu calçado era um tenisinho marrom. [...] Para mim, eu era uma rainha. [...] Como eu era feliz! [...] Pena que casei cedo por causa de madrasta.

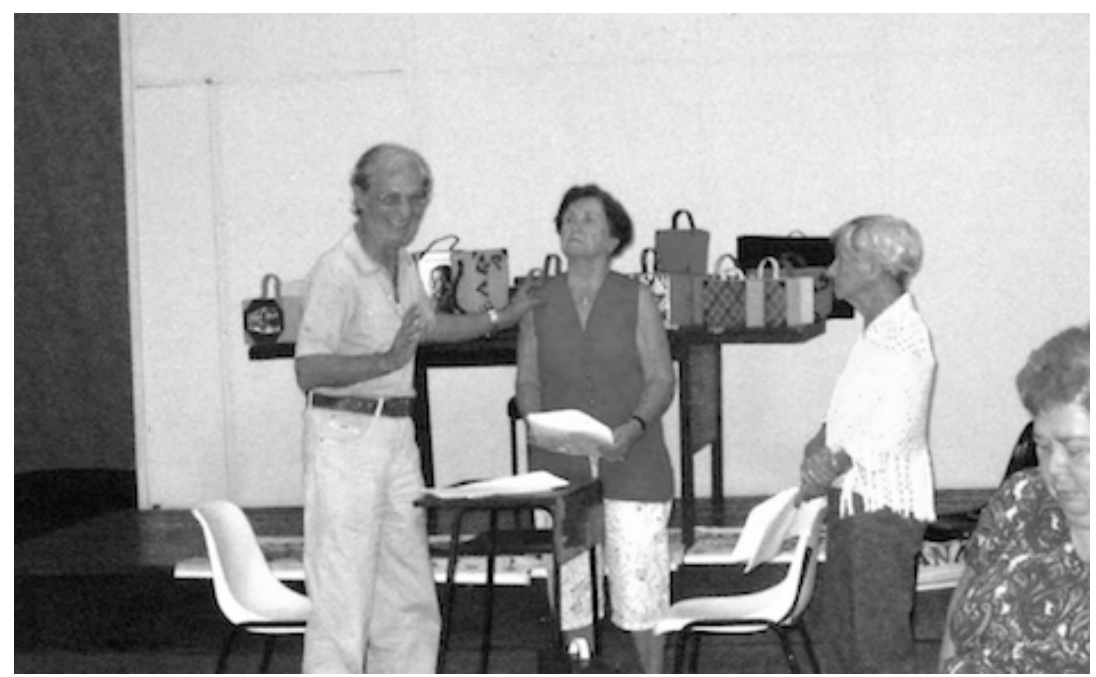

Imagem 25 - Andanças de um viajante

Referindo-se a segunda fotografia ${ }^{31}$, ressaltou a alegria de ter contracenado com este senhor que aparece na imagem. "Foi muito bom conhecer ele, era uma pessoa muito legal. Então escolhi esta porque representa as pessoas que já passaram por aqui, e também pela nossa vida, e como foi bom conhecer estas pessoas".

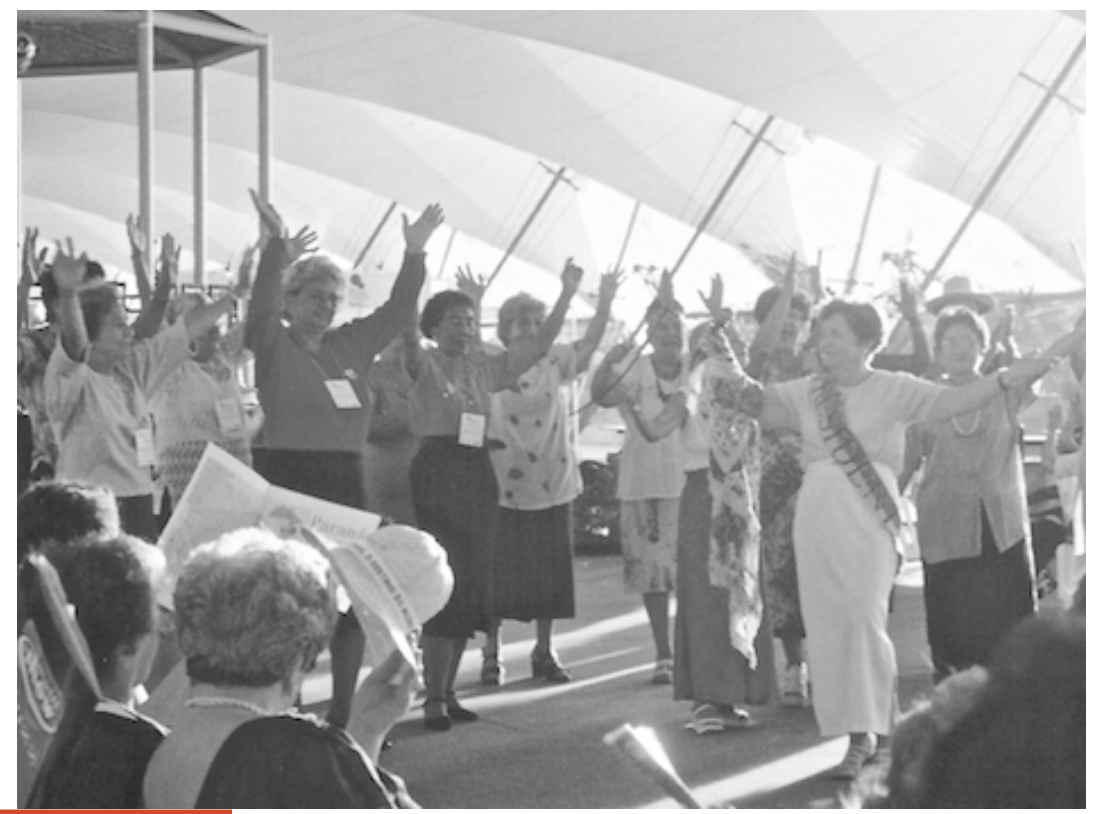

30 Niterói de nossas lembranças (2008). Nesta cena, Conceição representa uma avó conversando com a neta sobre acontecimentos na cidade quando era jovem. 31 Andanças de um viajante (2005). Nesta cena, Conceição representa com os outros uma das situações inusitadas vividas por este homem, em suas viagens de trabalho. 
Sobre a terceira foto ${ }^{32}$ ela comenta a importância de falarmos sobre o tema da mulher. "Esta aqui representou o que a mulher podia ser e pode ser. Então, pensar que a gente podia ser mais alguma coisa na vida, não pudemos, mas representamos. E esta aqui eu representei uma presidente. E você vê, agora temos uma presidente". Para uma menina que aprendeu a ler sozinha, lia por conta própria livros de história e geografia e, na adolescência, devorava a produção de Agatha Christie ${ }^{33}$ em detrimento da Coleção Biblioteca das Moças $^{34}$, tem razão em acreditar que, com oportunidade, poderia ter seguido outros caminhos. Aos catorze anos já trabalhava das seis às dezesseis horas em fábricas. Na primeira, a fábrica de fitas, começou enchendo carretel, uma semana depois já estava nos teares.

Aí, lá tinha tear que fazia renda, cada renda de um tipo, tinha tear que fazia fita, eu tava no tear da renda, quando arrebentava um fiozinho, pra gente pegar aquele fiozinho sem desligar a máquina, minha filha, era terrível. E depois quando fomos pra fábrica de fósforo marca Olho, no começo, eu colocava uma tela assim, ligava lá e enchia de fósforo, eu fiquei uma semana ali, enchendo aquelas telas, na segunda semana eu já estava tirando os fósforos dali e enchendo formas, com 15 dias eu já estava sentada, só ligando o negocio lá, eu ligava e a caixa de fósforos caía, eu botava pra colocar o carimbo. Se eu fico lá, eu ia acabar sendo gerente, porque eu olhava, gostava, perguntava, especulava, sabe, então eles achavam que eu tinha interesse.

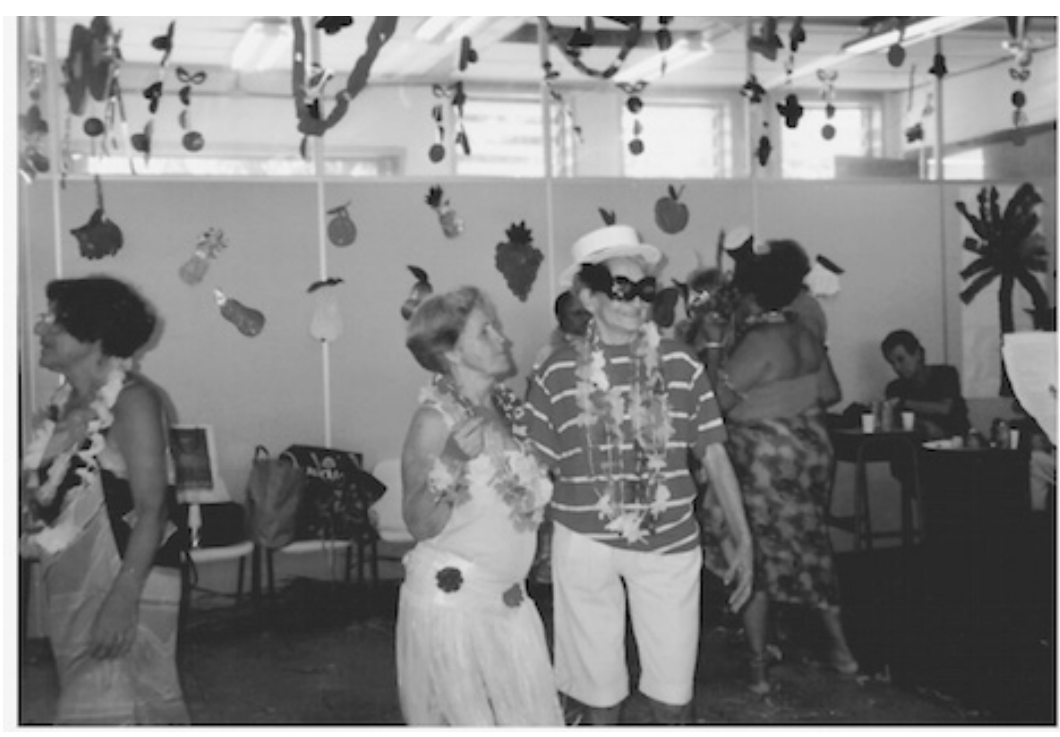

Imagem 27 - Baile do Havaí

Sobre a quarta fotografia 35 , lembrou que o roteiro havia sido escrito por Gabriela e tinha um casal, Diana e Guilherme, que se conheciam em um baile e se apaixonavam, mas depois não se viam mais. Dez anos após, ambos com casamentos desfeitos, tornam a se encontrar em um baile de carnaval. Na época, durante a discussão sobre o elenco, ela, imediatamente, se ofereceu para fazer a jovem.

32 Viva a mulher! (2000). Jogral apresentado na Marina da Glória (RJ), em homenagem ao dia da mulher. 33 Agatha Cristie (1890-1976), escritora inglesa conhecida pelos romances policiais.

34 Coleção de romances publicada pela Companhia Editora Nacional (SP), literatura direcionada às moças, entre 1940 a 1960

35 Ai que saudades do baile do Havai! (1999). 
Escolhi esta foto porque tem esta história do reencontro, da adolescência. E lembrei de mim. Eu namorei um rapaz um ano e depois terminamos. Mas nunca mais nos encontramos. Foi o primeiro namorado que eu tive. Não tinha nem 14 anos. Ele tinha vinte e poucos anos. Terminei porque encontrei ele com uma colega. Aí fiquei doente, eu era muito apaixonada por ele. Aí meu pai me levou para São Gonçalo, para a casa da minha irmã que tinha casado há pouco tempo. Então, arrumei trabalho na fábrica de fita. Depois na fábrica de fósforo marca olho. A fábrica fechou por causa da guerra. Voltei para a casa do meu pai e comecei a namorar o rapaz que depois casei. Então, traz estas lembranças da adolescência da gente, do que a gente passou e também do que não gostaria de ter passado. Olha, vou te contar, eu fui apaixonada por este rapaz, mas depois casei com outro.

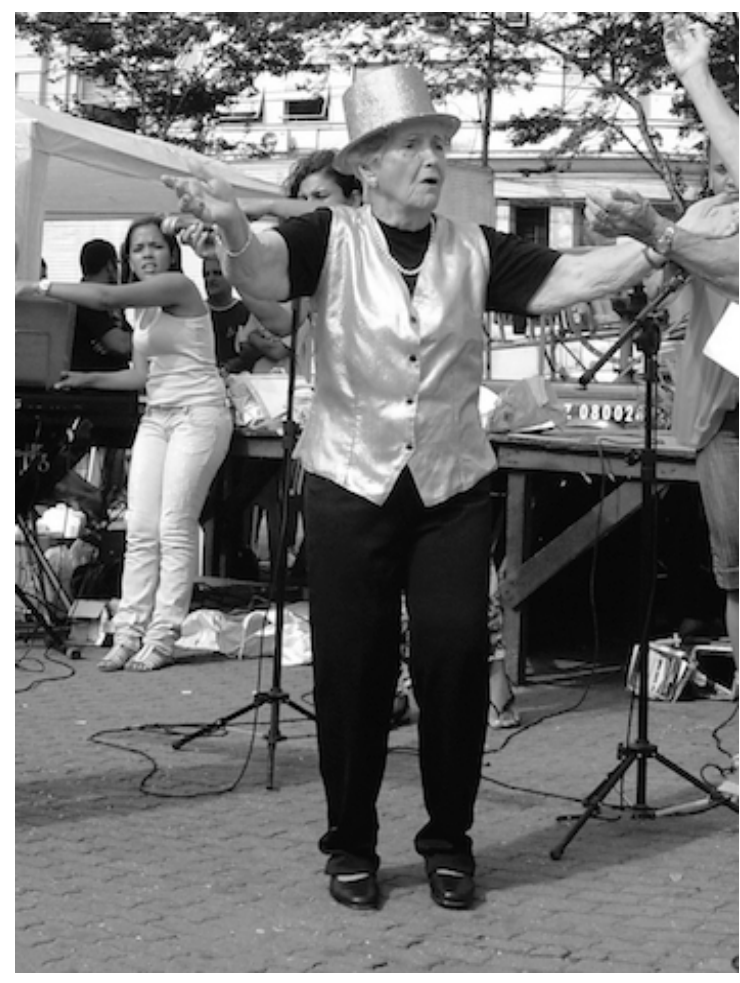

Imagem 28 - Cantoras do rádio

A quinta foto escolhida foi uma das apresentações de Rádio avançado no $a r !^{36}$, texto que tratava das memórias do grupo sobre a Era do Rádio. Nas entrevistas, várias foram as vezes que Conceição disse que sempre foi bonita, "[...] eu tinha os cabelos aqui [longos], ondulados e louros, os olhos tem dia que tá verde, tem dia que tá azul [...]", e que gostava de participar de tudo. Comentou sobre a escolha da foto em que aparece como uma das cantoras do rádio, que gostou muito de participar.

Em menina, eu gostava muito de cantar. A senhoria da casa onde eu morava, gostava de fazer umas apresentações. Ela pegava colcha e a gente fazia o cenário. Eu queria sempre fazer a bruxa, porque tinha mais coisa para falar, mas como eu era a mais bonita, tinha que fazer sempre a princesa.

Olhar para as fotografias escolhidas e falar sobre elas revelou uma Conceição que afirma ter o "dom de aceitar as coisas", mas com todas as adversidades jamais abriu mão de seu espaço na vida, da consciência de sua inteligência e beleza e da luta 
para conseguir a "personagem mais complexa".

\section{Algumas considerações}

O objetivo deste artigo foi trabalhar o material imagético, mais precisamente as fotos das apresentações teatrais, como ferramenta detonadora e organizadora de narrativas (Ferreira, 1996). As fotos apenas não seriam suficientes, mas sim o movimento que elas possibilitaram menos ou mais intensamente. Afinal, o que faz emergir a memória é sua interpretação, é seu poder de evocação e, sobretudo, este movimento provocado aqui pelas fotos, povoando as imagens fixas com vida e histórias. Foi ele que permitiu reencontrar as memórias. É este movimento que faz com que as fotos não sejam apenas relíquias de "uma memória acordada, desprovida de sentido e de possibilidade de estabelecer ligação com o passado." (Muxel, 2002, p. 169).

As quatro mulheres selecionadas para partilhar a experiência conosco se postaram diante das fotografias, selecionaram e ordenaram as imagens dos gestos cênicos, relacionanado-as com lembranças de suas vidas. E fizeram de modos bem distintos. No entanto, revelaram traços de modelos de família, educação e relações de sociabilidade. Arriscaríamos dizer que este exercício, para além de uma memória pessoal, alcança, com estas descrições de famílias e modos de viver, um registro que "é também social, familiar e grupal" (Bosi, 1994, p. 443).

O que poderíamos apontar como elementos em comum ou em paralelo que aparecem neste processo? O que as aproxima e as afasta?

Rosalina organizou as fotos numa sequencia de história de vida. Todas as cinco imagens funcionaram como a ponta do fio que puxava uma história de um período de sua vida. Ao mesmo tempo, o conjunto das cinco fotografias, em um incrivel trabalho de síntese, foi capaz de condensar seus setenta e quatro anos.

Eunice selecionou a primeira e a última foto, como ela era e como está agora, e depois escolheu as fotos "do meio", que considerou como momentos em que "estava bem". Se ela hesitou diante das fotografias embaralhadas das apresentações teatrais, mostrou total domínio quando nos apresentou a sua história pelas fotos de família. A ordenação já constava no álbum que, sem cerimônia, ela exibia. Revelou, assim, "um modo de ver a si próprio em uma rede de pseudo-presenças que expressam a imagem biográfica que se deseja deixar como legado" (Kim, 2003, p. 230).

Gabriela privilegiou o elemento afetivo, a maneira como a imagem chegou até ela para pensar sobre suas histórias, seus momentos especiais da vida. Conceição olhou para cada foto escolhida retirando ou valorizando um elemento na cena, seja uma pessoa ou uma situação. Este elemento a levou ao passado, recuperando histórias e experiências que viveu ou que não pode viver, mas foi possível representar no palco. Sem ordem cronológica ou qualquer outro tipo de preocupação sequencial, sua preocupação recaiu no valor simbólico presente no evento evocado pela foto.

O processo de seleção e organização das fotos feito por Rosalina priorizou uma trajetória cronológica da vida, partindo da infância até hoje. Eunice, rapidamente escolheu uma fotografia, a primeira, representativa de períodos de tristeza, como um marco zero. Na outra extremidade, a possibilidade do humor, da alegria, a capacidade de fazer rir, o que foi para ela uma grande descoberta. As três imagens do meio, escolheu assim, por escolher, para preencher. Tiveram o mesmo peso, o mesmo sig- 
nificado, "nestas eu estava bem". Enquanto Rosalina apresentou pelas fotos sua história em etapas, em momentos distintos, para Eunice é como se existisse apenas dois tempos, o da tristeza e o da liberdade.

Gabriela viu nas cinco fotos a possibilidade de fazer um balanço de momentos que the foram caros. Para Conceição, as fotos funcionaram como "start de lembranças" da cidade no tempo de sua juventude; das pessoas que conheceu na oficina; do que ela, como mulher, poderia ter sido e não foi; de um grande amor que ficou para trás; da possibilidade de representar uma cantora do rádio e de, enfim, ser uma estrela para nossas platéias.

Quando Eunice chegou com seus álbuns de família, sem acesso aos teóricos da memória e da imagem, de certo modo, sinalizou que "as fotografias são tecidos, malhas de silêncios e de ruídos. Precisam de nós para que sejam desdobrados seus segredos. As fotografias são memórias, histórias escritas nelas, sobre elas, de dentro delas, com elas" (Samain, 2012, p. 160). Foram estas histórias contidas nos gestos cênicos que procuramos fazer a leitura, mostrando modos de manifestação da memória. Fazendo uso da mesma ferramenta, fotos das apresentações teatrais, cada uma das mulheres desatou os nós de suas lembranças de maneira diferente, cada uma com a sua visada, de um lugar e tempo que ocupa hoje, com suas perspectivas peculiares, como acreditamos que acontece em qualquer exercício de memória.

\section{Referencias}

ACHUTTI, Luiz Eduardo Robinson. Fotoetnografia da Biblioteca Jardim. Porto Alegre: UFRGS Editora/Tomo Editorial, 2004.

ANDRADE, Jorge. Labirinto. Rio de Janeiro: Paz e Terra, 1978.

BOSI, Ecléa. Memória e sociedade. Lembranças de velhos. São Paulo: Companhia das Letras, 1994.

liê Editorial, 2003.

O tempo vivo da memória: ensaios de psicologia social. São Paulo: Ate-

BRUNO, Fabiana. Fotobiografia: por uma metodologia da estética em antropologia. 2009. 738p.Tese (Doutorado em Multimeios) - Instituto de Artes, Universidade Estadual de Campinas, Campinas, 2009.

Retratos da Velhice: um duplo percurso metodológico e cognitivo. 2003. 309p. Dissertação (Mestrado em Multimeios) - Instituto de Artes, Universidade Estadual de Campinas, Campinas, 2003.

COPQUE, B.; PEIXOTO, C. E.; LUZ, G.M. (org.) Famílias em imagens. Rio de Janeiro: Editora FGV, 2013.

DUBOIS, Philippe. O Ato Fotográfico e Outros Ensaios. Campinas: Papirus, 1994. 
FERREIRA, Maria Letícia M. Olhares fixos na imensidão do tempo. Fotografia e lembrança. Cadernos de Antropologia e Imagem 2. Rio de Janeiro: UERJ, 1996, p.115126.

LEJEUNE, P. O guarda-memória. Estudos Históricos, Rio de Janeiro, n.19, 1997.

KIM, Joon Ho. A fotografia como projeto de memória. Cadernos de Antropologia e Imagem, v.17, n.2, 2003.

KOSSOY, Boris. Fotografia e memória: reconstrução por meio da fotografia. In: SAMAIN, Etienne (org.). O Fotográfico. São Paulo: Senac, 2005.

MORAES, Daniela Lemos de. Autoimagem, fotografia e memória: contribuições de ex -internos do Asilo-Colônia Aimorés - SP. Campinas, SP, 2005. Dissertação (mestrado) MUXEL, Anne. Individu et mémoire familiale. Paris, Nathan, 2002.

NOVAES, Caiuby Sylvia. A construção de imagens na pesquisa de campo em antropologia. Iluminuras, Porto Alegre, v.13, n.31, p.11-29, jul./dez. 2012.

PEIXOTO, Clarice Ehlers. Envelhecimento e Imagem: As fronteiras entre Paris e Rio de Janeiro. São Paulo: Annablume, 2000.

tions in video-portrait 360, Dec. 2012. <http://www.scielo.br/scielo.php?script=sci_arttext\&pi$\mathrm{d}=\mathrm{S} 1809-43412012000200013 \& \mathrm{lng}=$ en\&nrm=iso>. Acesso em $07 \mathrm{Dec} .2015$. http://dx.doi.org/10.1590/S1809-43412012000200013

Memórias em imagens: uma evocação do passado. In: LOURY, Mauro Guilherme. Imagens e memoria. Ensaios em Antropologia Visual. Rio de Janeiro: Garamond, 2001, p. 173-187.

PEIXOTO, Clarice Ehlers; LUZ, Gleice Mattos. De uma morada à outra: processos de re-coabitação entre gerações. Revista Pagu (29), julho-dezembro de 2007:171-191.

POLLAK, M. Memória e identidade. Estudos Históricos, Rio de Janeiro, vol. 5, n.10, 1992, p.200-212.

SAMAIN, Etienne. Antropologia de uma imagem "sem importância". Ilha. Florianópolis, v.5, n.1, julho de 2003, p.47-64.

As peles da fotografia: fenômeno, memória/arquivo, desejo. Visualidades. Goiânia, v.10, n.1, p.151-164, jan-jun 2012. 
(Org.). O Fotográfico. São Paulo: Senac, 2005.

. Quando a Fotografia (já) fazia os antropólogos sonharem: o Jornal 'La Lumière' (1851-1860) (2). In: FABRIS, Annateresa; KERN, Maria Lúcia Bastos. (Org.). Imagem e Conhecimento. 1 ed., v. 1, São Paulo: EDUSP, 2006(a). p. 193-227.

SIMSON, O. R. M. Imagem e memória. In: SAMAIN, Etienne (Org.). O Fotográfico. São Paulo: Senac, 2005.

Recebido em: 26/04/2016 Aprovado em: 10/08/2016 